\title{
Post-rift extensional tectonics at the edge of a carbonate platform: insights from the Middle Jurassic-Early Cretaceous Monte Giano stratigraphic record (central Apennines, Italy)
}

\author{
Franco Capotorti and Cristina Muraro* \\ Institue for environmental Research and Protection (ISPRA) \\ Department for the Geological Survey of Italy, Via V. Brancati, 48, 00144, Rome, Italy \\ Caporoti E-mail: franco.capotorti@isprambiente.it. Muraro E-mail: cristina.muraro@isprambiente.it
}

${ }^{*}$ Corresponding author

A B S T R A C T

A new interpretation of the Middle Jurassic-Early Cretaceous paleogeographic evolution of the NW sector of the Latium-Abruzzi carbonate platform facing the Umbria-Marche Basin is proposed, based on Monte Giano area (central Apennines, Italy). During Late Triassic-early Bajocian time, the area was characterized by shallow water sedimentation. Inner and marginal carbonate platform deposits are overlain by pelagic deposits (Posidonia level), early Bajocian p.p. in age. This unconformity testifying the sudden drowning of the Monte Giano area, while shallow water sedimentation persisted in the remaining sectors of the carbonate platform. The Posidonia level is paraconformably overlain by distal slope deposits of the Velino Gorge limestones Formation, Kimmeridgian p.p.-Tithonian p.p. in age. Therefore, a 12Ma gap is recorded as in the Umbria-Marche Basin pelagic carbonate platforms. An extensional Bajocian tectonic phase, possibly related to the Piemont-Ligurian Ocean opening coupled with rheologic differences at the basin/platform boundary, drastically changed the regional paleogeography causing the breakup and the drowning of the NW sector of the Latium-Abruzzi carbonate platform and the creation of a large flat-topped pelagic carbonate platform. The estimate offset of the early Bajocian fault is around $300-350 \mathrm{~m}$. The Velino Gorge limestones fm. pass laterally and vertically to the Upper Tithonian platform-margin reef complex of the Ellipsactinia limestones fm.; these units constitute a shallowing and coarsening upward sequence and levelled the paleobathymetric gradient created by the Bajocian extension. The progradation of the Latium-Abruzzi carbonate platform continued during Early Cretaceous time. These results have strong implications on the tectonic and paleogeographic evolution of the major domains of the central Apennines. 


\section{INTRODUCTION}

The central Apennines in central Italy record the geodynamic evolution of the western Tethys Ocean from rifting to subduction/collision (Manatschal and Bernoulli, 1998). The Late Triassic was a time of dominantly evaporitic sedimentation (Anidriti di Burano Formation (Fm.)) evolving to carbonate platform sedimentation documented regionally by the Rhaetian Monte Cetona Fm. (Ciarapica and Passeri, 2005), Dolomia Principale Fm. (Adamoli et al., 1990) and the Hettangian-early Sinemurian Calcare Massiccio Fm. An early Sinemurian rifting phase caused the fragmentation of this vast carbonate platform (Bernoulli, 1967, 1971; Centamore et al., 1971), producing the individualization of the pelagic Umbria-Marche Basin and of the Latium-Abruzzi carbonate platform (Fig. 1). The Umbria-Marche Basin was characterized by a complex pattern of structural lows and isolated highs (Bice and Stewart, 1990), the latter named Pelagic Carbonate Platforms (PCPs) (Galluzzo and Santantonio, 2002; Santantonio, 1993; 1994; Santantonio et al., 2017, and references therein). The Latium-Abruzzi platform was characterized by persistent shallow-water carbonate sedimentation until middle or late Miocene p.p. time, although episodes of drowning at its marginal sectors occurred during the Late Cretaceous (Capotorti et al., 1991, 1995; Dela Pierre, 1994).

During the Middle-Late Jurassic, the sedimentary evolution of the pelagic basin and the carbonate platform of central Apennines were mainly influenced by paleoceanographic changes and eustasy (Morettini et al., 2002), while tectonics played only a minor role, as evidenced by the studies carried out in this region, which generally contain little indication of extensional activity younger than the late Hettangian-early Sinemurian rifting phase (Di Francesco et al., 2010; Donatelli and Tramontana, 2010; 2012; Galluzzo and Santantonio, 2002; Leonardi et al., 1997).

At late early Bajocian time, the Umbria-Marche Basin recorded an important change from calcareous to dominantly siliceous sedimentation, which persisted in the western Tethys realm for a time span of $\sim 12 \mathrm{Ma}$ (early Bajocian p.p. to earliest Kimmeridgian; Cohen et al., 2013). Actually, much of the carbonate mud in the pelagic successions was periplatform ooze-derived from peritidal platforms, at least until the early Tithonian (Bombardiere, 1993; Cobianchi and Picotti, 2001). The lack/scarcity of carbonate mud in the basins might therefore indicate a crisis of the mud carbonate factory and/or a turnover of carbonate producers. From Bajocian p.p. up to the Oxfordian-early Kimmeridgian, the widespread inner carbonate platform deposits in the central Apennines document an abnormally long-lasting standstill, with no lateral migration or change in facies and biota (Chiocchini et al., 1994; Damiani et al., 1991b, 1998) and low sedimentation/subsidence rates (Colacicchi and Bigozzi, 1995). Furthermore, a synchronous depositional gap, ranging from the late early Bajocian p.p. to the late early Kimmeridgian is well documented on all of the PCPs (Cecca et al., 1990; Centamore et al., 1971; Farinacci, 1967; Santantonio, 1993, 1994) across the Umbria-Marche Basin.

Within this general context, we focused our attention on the Monte Giano area in the north-western sector of the Latium-Abruzzi platform during the Jurassic-Early Cretaceous interval, which has been traditionally interpreted as representing the transition between the Latium-Abruzzi platform and the Umbria-Marche Basin (Fig. 1). Based on new geological mapping, stratigraphic sections, facies analysis and micropaleontological constraints, we propose a new interpretation for the post-rifting Middle JurassicEarly Cretaceous evolution of this sector of the central Apennines.

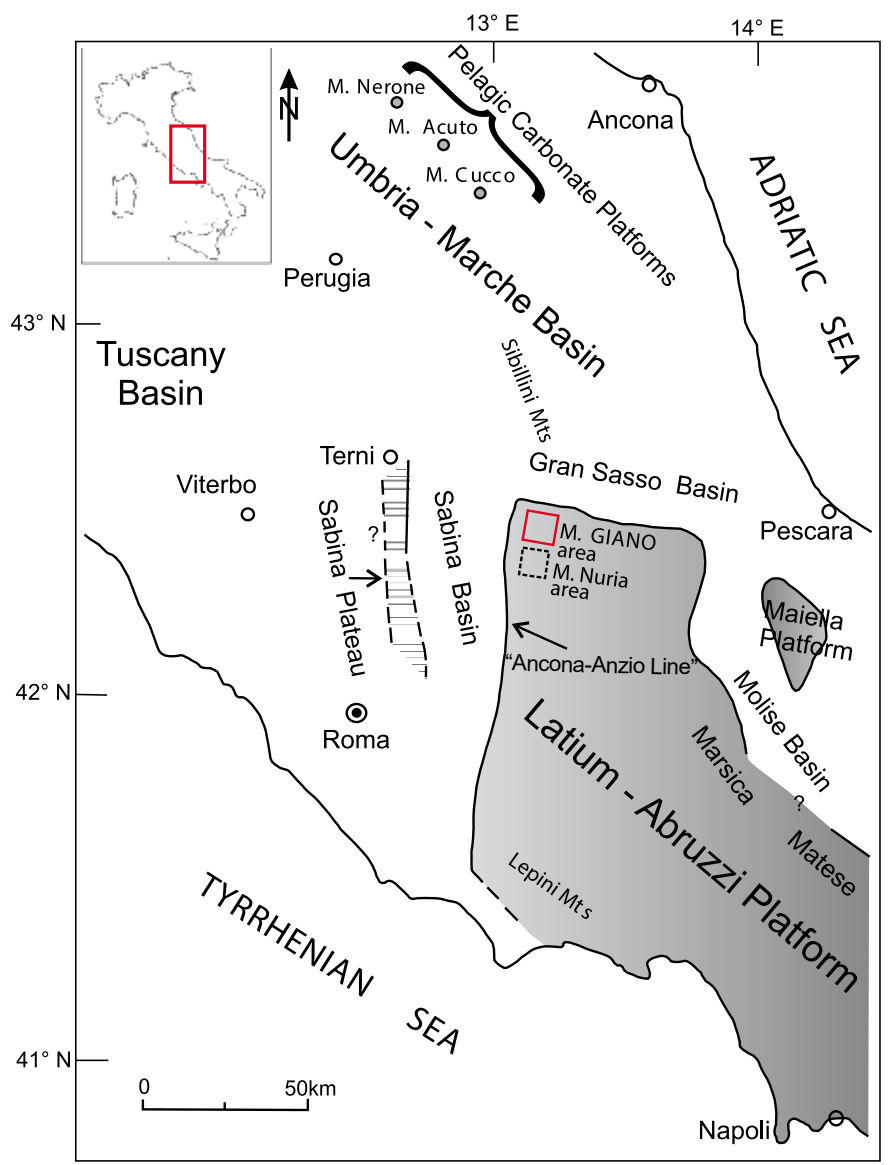

FIGURE 1. The main Jurassic (post early Sinemurian) paleogeographic domains of central Italy (grey areas represent carbonate platforms). Modified after Galluzzo and Santantonio (2002). The red box in the Latium-Abruzzi platform represents the area of Figure 3. 


\section{Geological setting}

The Monte Giano area constituted the northwesternmost sector of the Latium-Abruzzi platform, bounded to the NW by the Umbria-Marche Basin (Fig. 1). As the sector of the Umbria-Marche Basin proximal to the carbonate platform, the study area contains abundant platform-derived resedimented deposits. It is divided to the West and North into the Sabina sub-basin (Morettini et al., 2002) and the Gran Sasso sub-basin (Centamore et al., 1991a) respectively (Fig. 1). The differentiation of these paleogeographic domains, originally hosting homogeneous shallow water sedimentation (Calcare Massiccio Fm.), started around the Hettangian/Sinemurian boundary after an extensional tectonic phase (Castellarin et al., 1978; Ciarapica and Passeri, 1998, 2002) related to the western Tethys rifting (Bernoulli, 1967, 1971; Ciarapica, 2007; Santantonio and Carminati, 2011, and references therein). The boundary between the Sabina sub-basin and the Latium-Abruzzi platform is a west-dipping fault named "Ancona-Anzio Line" Auctt. (Fig. 1) (Castellarin et al., 1978; Cavinato et al., 1986; Devoto and Praturlon, 1973; Migliorini, 1950). The boundary between the Gran Sasso sub-basin and the Latium-Abruzzi platform is not exposed, most probably being a north-dipping fault (Castellarin et al., 1978; Scarsella, 1951).

The Latium-Abruzzi platform succession is characterized by more than $3000 \mathrm{~m}$ of Upper Triassic-Miocene $p . p$. shallow water carbonate sediments (monotonous dolostone and limestone sequences with several hiatuses) (Damiani et al., 1991a). In contrast, in the western and north-western edges of the Latium-Abruzzi platform the carbonate platform facies persisted until the early Late Cretaceous, when a combination of different factors such as a marine transgression, a global paleonvironmental crisis and an extensional tectonic phase caused a diachronic drowning (Capotorti, 1993; Capotorti et al., 1995; Centamore and Dramis, 2010; Farrimond et al., 1990). In these external areas, the Upper Cretaceous p.p.-Miocene p.p. calcareousmarly succession documents an evolution from downfaultedblock to outer ramp environment, followed by Messinian $p . p$. foredeep siliciclastic turbiditic deposits.

The Sabina and Gran Sasso sub-basins exhibit successions of up to $2000 \mathrm{~m}$ of Lower Jurassic-Upper Miocene pelagic sediments, composed of limestones, cherty limestones and marls/shales, with abundant resedimented shallow water deposits (Centamore et al., 1991a; Di Francesco et al., 2010; Parotto and Praturlon, 1975; Scarsella, 1951).

The geological setting of the Monte Giano area (Figs. 2; 3 ) is the result of a polyphasic tectonic history. After the Early Jurassic rifting, tensional tectonic phases occurred during
Late Coniacian and Paleogene times, causing the drowning and the down-stepping of this sector of the Latium-Abruzzi platform (Capotorti et al., 1991, 1995). At Late Miocene time, another extensional tectonic phase displaced or reactivated the Early Jurassic faults. This tectonic phase could be linked with lithospheric flexure and contemporary buckling and bending, leading to the dismembering of the foreland/ foredeep system (Calamita et al., 2003; Patacca et al., 1992; Royden et al., 1987; Tavarnelli et al.,, 1999). At late Mioceneearly Pliocene time, the area experienced a tectonic inversion connected with the Alpine orogeny due to convergence of the African-Adria and European continental margins (Boccaletti et al.,1990; Carmignani and Kligfield, 1990; Carminati et al., 2012; Doglioni, 1991), which gave way to thrusts with top-to the NE sense of movement. This phase produced a regional overthrusting of the Umbria-Marche domain over the Latium-Abruzzi platform domain, through the E-NE-directed Olevano-Antrodoco-Sibillini mountains thrust (Fig. 2) (Calamita et al., 1987; Calamita and Deiana, 1988; Cavinato et al., 1986; Coli, 1981; Funiciello et al., 1980; Pierantoni et al., 2013; Salvini and Vittori, 1982), which possibly reutilized the older Early Jurassic extensional "Ancona-Anzio Line" fault zone (Castellarin et al., 1978; Di Domenica et al., 2012). During this phase, minor overthrusting of the Latium-Abruzzi platform domain over the Gran Sasso sub-basin is also documented by the Monte Gabbia-Monte Calvo thrust (Fig. 2) (Capotorti et al., 1995; Centamore et al., 1991b; Salvucci, 1995; Vezzani et al., 1994). At late Pliocene/Pleistocene times, a further extensional tectonic phase is recorded in the whole central Apennine, with NW-SE striking faults. This phase has been correlated with the opening of the Tyrrhenian back-arc basin (Gueguen et al., 1997; Patacca et al., 1992).

Nowadays, the Monte Giano area is a north-dipping monocline that exposes Upper Triassic-middle Miocene rocks, and is bounded by the NNE-SSW Olevano-AntrodocoSibillini mountains thrust to the West, the late Miocene NWSE-striking normal Antrodoco fault to the South, and the WNW-ESE Monte Gabbia-Monte Calvo thrust (partly blind) to the North and North-East (Fig. 2). The Antrodoco fault separates the Monte Giano external sector from the more internal Monte Nuria sector of the Latium-Abruzzi platform. Furthermore, the Monte Giano area is strongly dissected by a dense pattern of Cretaceous-Miocene syn-sedimentary faults and post-orogenic late Pliocene-Pleistocene NW-SE trending normal faults (Fig. 3).

\section{STRATIGRAPHY}

\section{Monte Giano area}

The Monte Giano succession crops out in a steep mountainous, structurally segmented area, often characterized by poor exposure conditions. Eight 


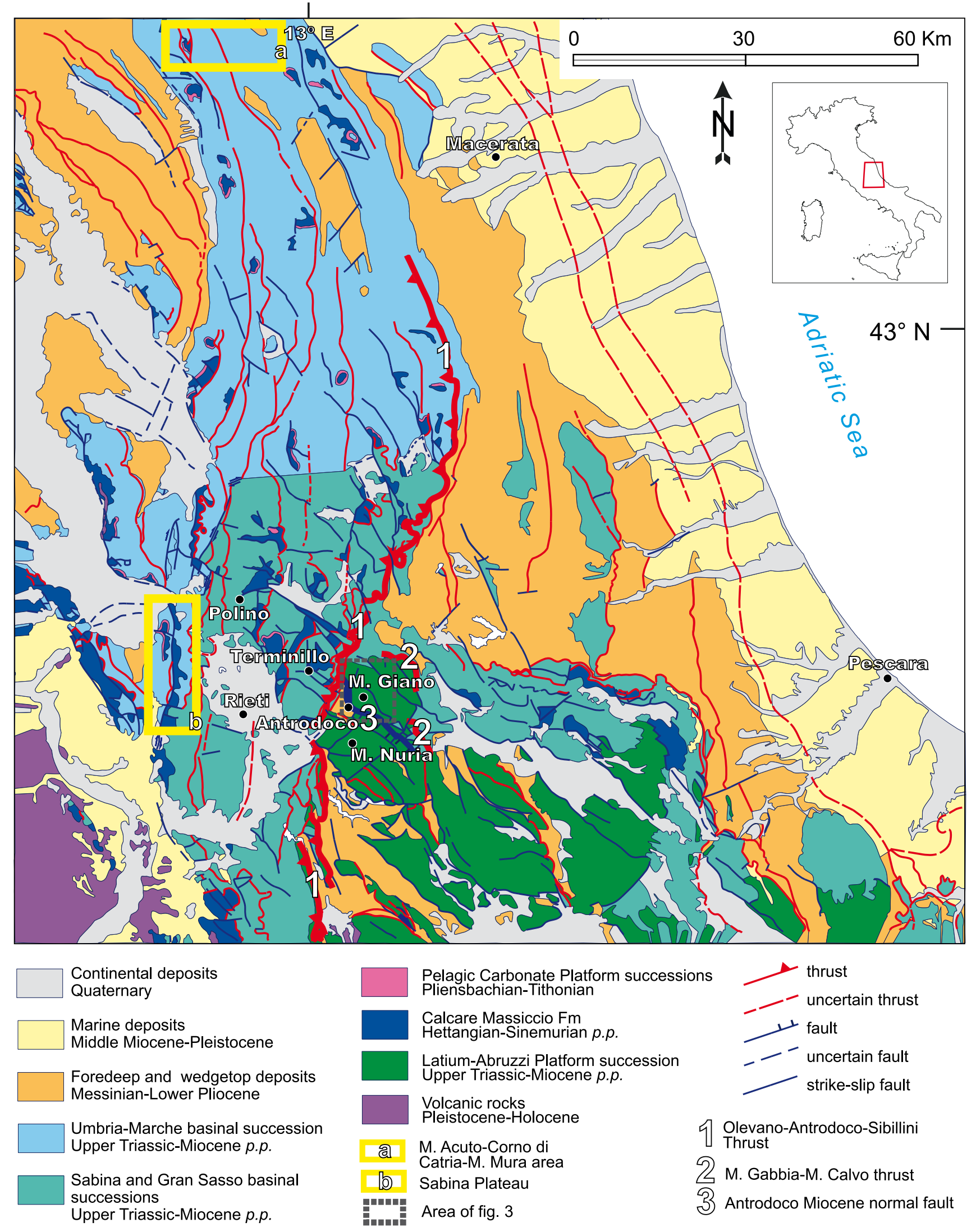

FIGURE 2. Simplified geological map of central Apennines (Modified after Servizio Geologico d'Italia, 2011). 
stratigraphic sections representative of the geology across the study area are reported (Figs. 3; 4). More than 1000 thin sections were analysed to determine the facies and the age of the identified lithostratigraphic units. These formations are currently used in the National Geological Map of Italy Project (CARG Project; https://www.isprambiente.gov.it/ Media/carg/), at 1:50.000 scale, even though only few of them have been formalized. These units will be briefly described below, from bottom to top.
Dolomia Principale and Calcare Massiccio Fms. These two units are made up of prevalent crystalline dolostones with subordinate dolomitic wackestones and packstones, organized in m-scale shallowing-upward cycles. The total exposed thickness is about $600 \mathrm{~m}$. The depositional environment was a restricted platform in hothumid climate (Dolomia Principale Fm.), evolving into an open flat-topped carbonate platform (Calcare Massiccio Fm.). The age ranges from Rhaetian to Sinemurian p.p.

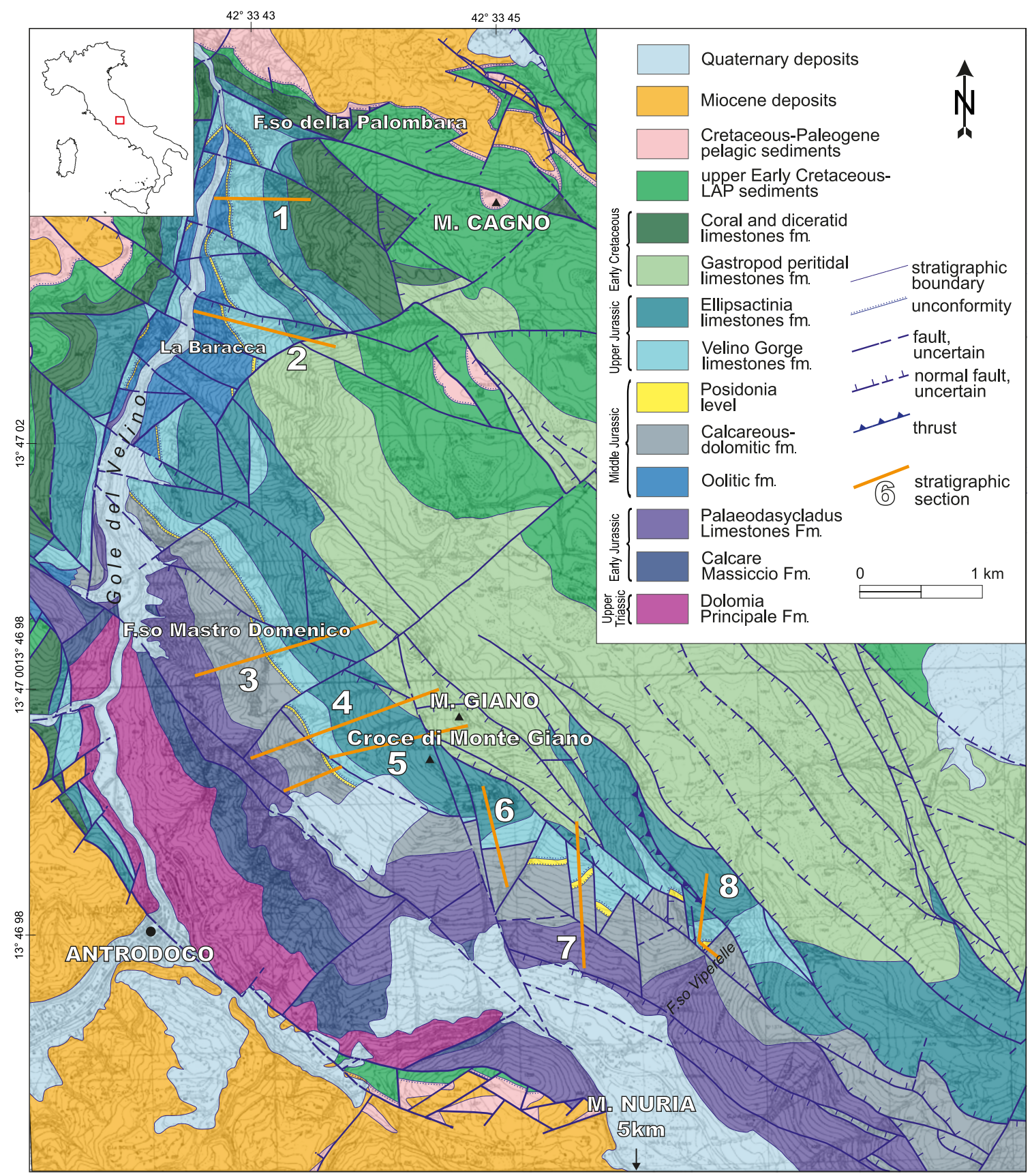

FIGURE 3. Simplified geological map of the Monte Giano area showing the location of the stratigraphic sections reported in Figure 4. LAP: Latium-Abruzzi carbonate platform. 
Palaeodasycladus Limestones Fm. This formation is made up of mudstones and wackestones, with interbedded medium to thick-bedded bio-intraclastic packstones, palebrown, grey and white in color, with peloids, ooids, and coated grains. In the lower part, dolomitic limestones and dolostones frequently occur in the western part of the study area. The middle part of the formation is characterized by floatstones with large bivalves, corals, gastropods, layers with abundant foraminifers (Orbitopsella praecursor), and pisoids and centimetric oncoids. The microfossil content includes algae, Palaeodasycladus mediterraneus, Palaeodasycladus elongatus, Thaumatoporella parvovesiculifera, and foraminifers, Orbitopsella primaeva, Orbitopsella praecursor, Lituolipora termieri, Haurania deserta, Lituosepta recoarensis, Amijiella amiji, Involutina farinacciae, Siphovalvulina variabilis, Meandrovoluta asiagoensis, Duotaxis metula, Aeolisaccus dunningtoni. The thickness of this unit is about $300 \mathrm{~m}$. The depositional environment was the inner part of a flat-topped platform (cfr. Patacca and Scandone, 2013), with broad protected and periodically emergent areas. The fossil association indicates a Sinemurian p.p.-early Toarcian p.p. age.

Calcareous-dolomitic fm. It consists of white and whitish mudstones and wackestones with birdseyes and fenestrae, benthic foraminifers, gastropods and algae. It contains interbedded fine-grained packstones with peloids and coated grains, oolitic packstones-grainstones and oolitic-oncolitic floatstones (Fig. 5A) to rudstones, often dolomitized. Thick dolostone beds and rare thin greenish clay beds also occur. The foraminifers are Bosniella croatica, Protopeneroplis striata, Marzoella ficcarelli, Callorbis minor, Gutnicella cayeuxi, Gandyina sp., Haurania deserta, Trochammina sp., Trocholina sp., Redmondoides lugeoni, plus nodosarids and valvulinids. The algae are Selliporella donzelli. Other biotic components are corals, bivalves, gastropods, echinoid fragments and ostracods. The facies indicates an inner carbonate platform environment. The thickness ranges between 250 and $300 \mathrm{~m}$. The age is Toarcian p.p. - early Bajocian p.p.

Oolitic fm. It is made up of well-bedded packstones to grainstones (Fig. 5B), white and grey in color, with ooids, oncoids and peloids, alternating with locally dolomitized grey wackestones and mudstones with bioclasts and different types of coated grains. The paleontological content is the same as the coeval calcareous-dolomitic unit due to the lateral transition between these units. The absence of sedimentary structures typical of oolitic bars (cross bedding, cross lamination, etc.) prevents us from assigning this unit to the platform edge but, more properly, allow us to ascribe this unit to an inner-outer platform environment. These facies are interpreted as the result of the redistribution of ooid-rich sediment towards the inner part of the carbonate

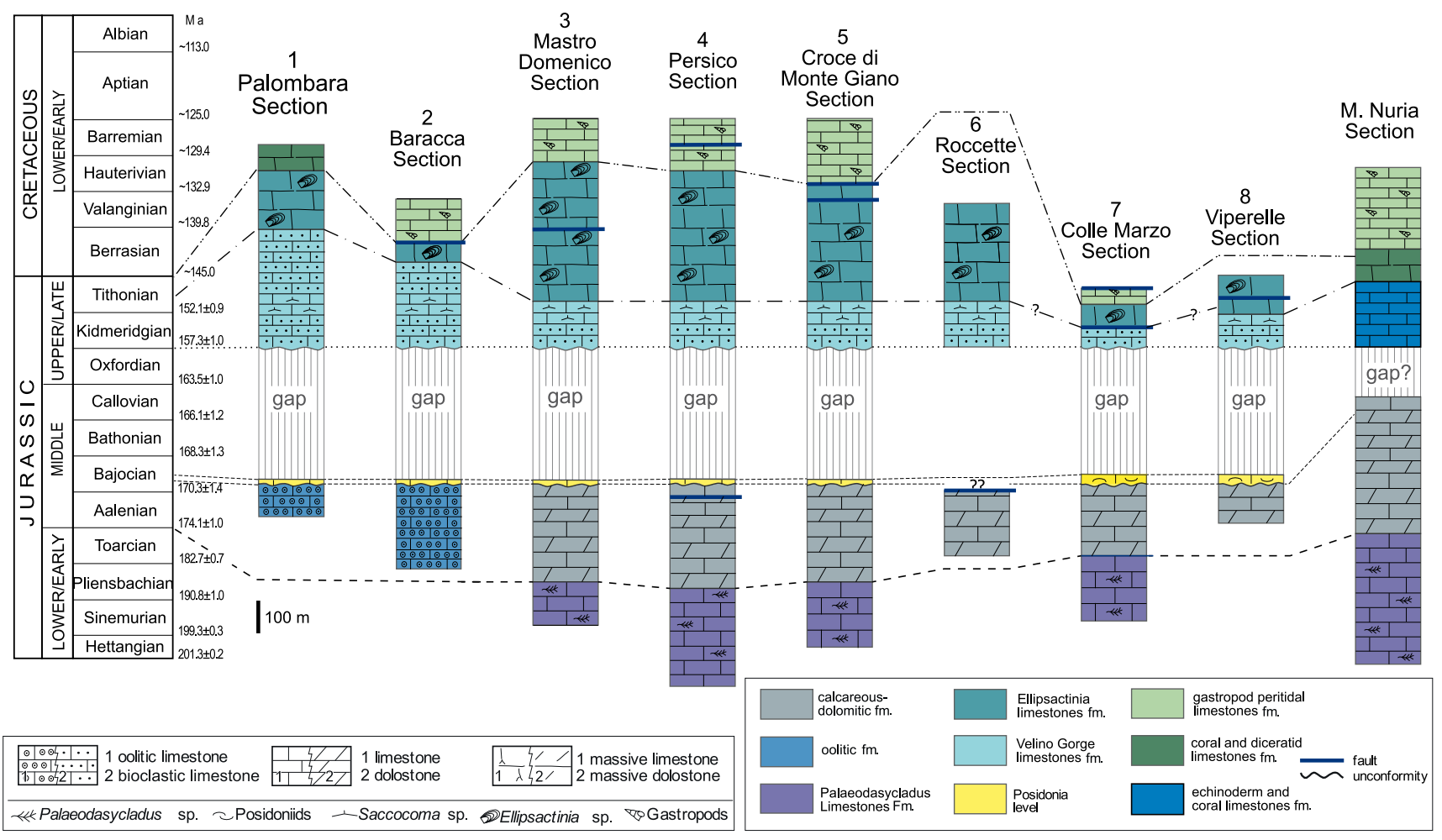

FIGURE 4. Stratigraphic sections of the Monte Giano area and their correlation with the Monte Nuria Section. Time scale from Cohen et al. (2013, updated). 
platform, forming washover fans or storm washovers. This unit replaces the calcareous-dolomitic fm. in a more external environment (northwards in Fig. 3). The thickness is about $300 \mathrm{~m}$. The age is Toarcian p.p. - early Bajocian p.p.
Posidonia level. All across our study area, the oolitic and calcareous-dolomitic units are overlain by wackestones and packstones rich in Posidonia Auctt. (thin-shelled bivalves, Conti and Monari, 1992) (Fig. 5C-D). Other biotic components
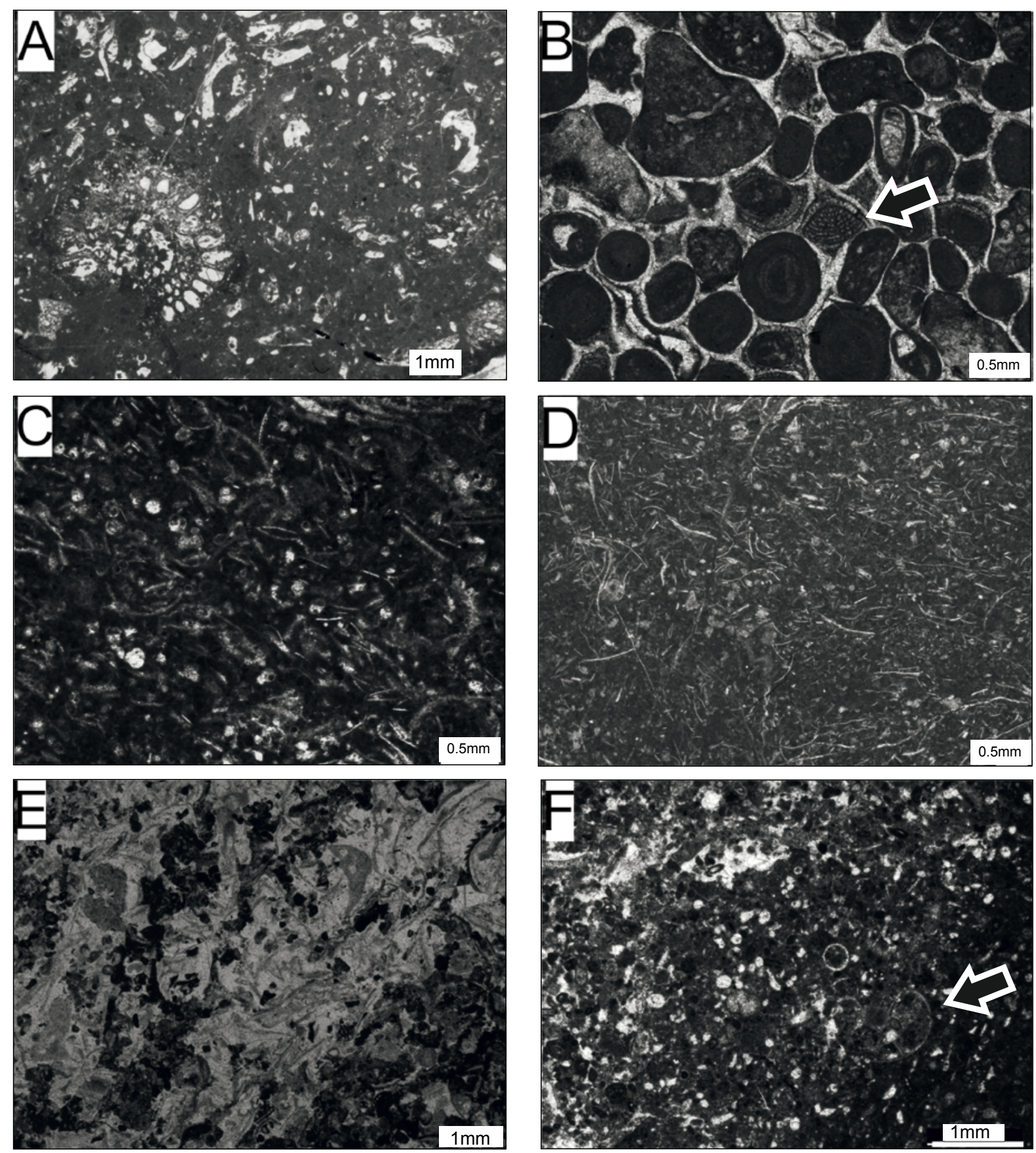

FIGURE 5. Microfacies of the Monte Giano area. A) Calcareous-dolomitic fm. Floatstone with Selliporella donzelli. B) Oolitic fm. Packstone/ grainstone with ooids and Gutnicella cayeuxi (arrowed), echinoderm and mollusk fragments. C) Posidonia level. Packstone with thinshelled bivalves, Globuligerina sp., radiolarians, sponge spicules. D) Posidonia level. Bioclastic packstone with thin-shelled bivalves and rare echinoderm fragments. E) Velino Gorge limestones fm. Recrystallized bioclastic packstone with Saccocoma sp., Tubiphytes morronensis, aptychus and echinoderm fragments. F) Velino Gorge limestones fm. Partly recrystallized packstone with radiolarians, sponge spicules, a small ammonite (arrowed), echinoderm fragments and probable Saccocoma sp. 
are small ammonites, aptychi (ammonite jaw parts), benthic foraminifers (Lenticulina sp, nodosarids), the planktonic foraminifer Globuligerina oxfordiana, and radiolarians. Shallow water platform-derived bioclasts together with peloids, glauconite grains and soft micritic pebbles are the other conspicuous components. The coccolith Carinolithus superbus and the calcareous nannofossil Watznaueria sp. are also present. The boundary with respect to the underlying units is a simple bedding plane, indicating a drowning unconformity. The thickness ranges from $4 \mathrm{~m}$ (North) to $22 \mathrm{~m}$ (South). This level indicates a pelagic environment of early Bajocian p.p. age.

Velino Gorge limestones fm. The lower part of this formation is made up of well-bedded, fine-grained
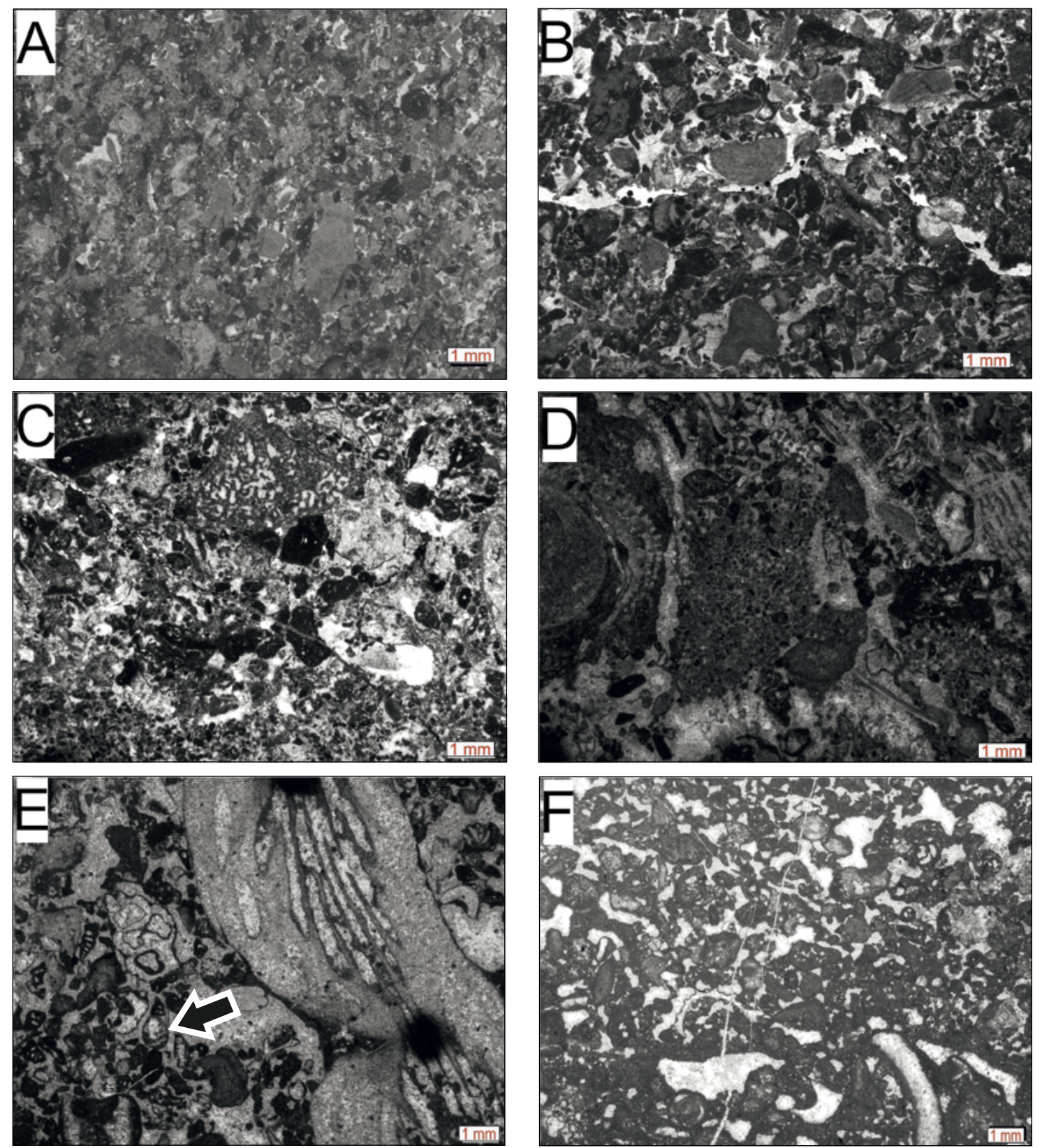

FIGURE 6. Microfacies of the Monte Giano area. A) Velino Gorge limestones fm. Packstone with echinoderm fragments scattered, Tubiphytes sp., rare radiolarians, Saccocoma sp. B) Velino Gorge limestones fm. Bioclastic packstones-grainstones with echinoderm fragments, Tubiphytes sp., pellets, Protopeneroplis sp., Trocholina sp., radiolarians, Stomiospherids (?Cadosina carpatica). C) Ellipsactinia limestones fm. Rudstone with large fragments of hydrozoans, Tubiphytes morronensis, echinoderm and bivalve fragments. D) Ellipsactinia limestones fm. Rudstone with Tubiphytes morronensis, Ellipsactinia sp. and badly preserved echinoderm fragments. E) Coral and diceratid limestones fm. Rudstone with a large transverse section of coral, gastropod and echinoderm fragments, Trocholina campanella (arrowed), Valvulina alpina. F) Gastropod peritidal limestones fm. Fenestral bindstone with small-sized benthic foraminifers. 
bioclastic packstones and minor wackestones (Fig. 5EF), whereas the medium and the upper parts consist of well-bedded bioclastic packstones-grainstones (Fig. 6A-B) evolving upward to massive bioclastic rudstones. In the southern part of the Monte Giano area (Mastro Domenico and Viperelle sections, Fig. 4), thin bedded mudstones-wackestones with aptychi and pelagic crinoids (Saccocoma sp.) are interbedded with fine-grained packstones-grainstones in the lower part of the formation. In the Viperelle section, chert ribbons and nodules also occur. The fossil content includes typical pelagic organisms like radiolarians, calcareous dinoflagellate cysts (stomiospherids), Saccocoma sp., sponge spicules, aptychi and small ammonites (Fig. 5E-F), along with platform-derived material like abundant echinoderm fragments, hydrozoans, solitary corals, bivalve fragments, large echinoid spines, hydrozoans (ellipsactinids), miliolid and nodosarid foraminifers, algae, microproblematica and coated grains. The identified forms include Tubiphytes morronensis, the foraminifers Labyrinthina mirabilis, Mohlerina basiliensis, Nautiloculina oolithica, Protopeneroplis sp., Lenticulina sp., Trocholina sp., the algae Muranella parvissima, Salpingoporella pygmea, Lithocodium aggregatum, Pseudolithocodium carpathicum and the serpulid Mercierella dacica. This formation rests paraconformably on the Posidonia level. At outcrop scale, the boundary is conformable (Figs. 7; 8; 9) without any obvious sedimentological evidence typical of an omission surface, such as a mineralized hardground or lag deposits. This formation records a distal to inner slope facies evolution dominated by gravity flow deposits remarkably increasing upwards. Therefore, it represents a shallowing and coarsening upward sequence. The thickness ranges between 120 and $350 \mathrm{~m}$ from the southern to the northern part of the area, where the Velino Gorge limestones pass laterally to the lower part of the Ellipsactinia limestones (Fig. 4). The age of the formation is Kimmeridgian p.p.Tithonian p.p.

Ellipsactinia limestones $\mathbf{f m}$. This unit typically consists of massive bioclastic packstones to rudstones (Fig. 6C-D), with abundant ellipsactinids, echinoderm fragments, corals and chaetetids, as well as bivalve fragments, bryozoans, calcareous sponges and gastropods. The microfossil content includes: Tubiphytes morronenis, Koskinobullina socialis, the alga Salpingoporella gr. pygmaea, the foraminifers Protopeneroplis ultragranulata and Trocholina sp., rare radiolarians, calpionellids, stomiospherids, Mericerella dacica? and Saccocoma sp. This unit is a shallowing and coarsening upward sequence, which testifies the progradation of the margin of the Latium-Abruzzi platform onto the previous slope, with large-scale clinoforms made up of shallow water debris. The occurrence of rare pelagic organisms (Saccocoma sp., radiolarians and calpionellids) testifies sedimentation developed on a very broad marginal environment (Rusciadelli and Ricci, 2013) with unrestricted water circulation. The thickness ranges between 400 and $180 \mathrm{~m}$, from the southern to the northern part of the area, due to the lateral transition with the Velino Gorge limestones Fm. The age is late Tithonian.

Coral and diceratid limestones $\mathbf{f m}$. This unit is made up of medium- to thick-bedded rudstones (Fig. 6E), grainstones and floatstones, locally of bindstones, with abundant corals, echinoderm fragments, hydrozoans, bivalves, gastropods and calcareous sponges. The lower part of this unit contains diceratid rudist-rich layers, whereas the medium and upper parts are characterized by abundant caprotinid rudists, associated with requieniid rudists and large gastropods. In the northern part of the study area, there are intercalations of bioclastic packstones and grainstones and less common wackestones of external platform to upper slope facies, with sponge spicules, rare radiolarians, aptychi, and soft pebbles whit calpionellids (Calpionellopsis simplex and Calpionellites darderi). The microfossil content includes: the algae Lithocodium aggregatum and Bacinella irregularis, Tubiphytes morronensis, the foraminifers Protopeneroplis ultragranulata, Haplophragmoides joukowskyi, Valvulina alpina, Mohlerina basiliensis, Pseudocyclammina lituus, Trocholina spp., Mesoloculina histri, Coscinophragma cribrosum, Neotrocholina infraganulata and de serpulid Mercierella dacica. The facies variability indicates a marginal carbonate platform environment and its lateral transition towards the inner platform southwards (more common) and the upper slope northwards (e.g. facies with pelagic elements). The thickness is about $250-300 \mathrm{~m}$ and the age is upper-late Tithonian-Barremian p.p.

Gastropod peritidal limestones fm. This unit consists of peritidal limestones (Fig. 6F), organized in m-scale shallowing-upward cycles, with frequent subaerial exposure surfaces. The subtidal deposits, in the lower part of the unit, are fine-grained grainstonespackstones, bioclastic grainstones and wackestonespackstones with oncoids, calcareous algae and benthic foraminifers. The intertidal deposits are mudstones with birdseyes and fenestrae. The upper part of the unit is made up of mudstones and wackestones with birdseyes and biomicrites containing requieniids and gastropods. The microfossil content comprises: the algae Lithocodium aggregatum, Bacinella irregularis, Salpingoporella annulata, Salpingoporella gr. pygmea, Triploporella neocomiensis, Clypeina solkani, the foraminifers Mohlerina basiliensis, Protopeneroplis ultragranulata, Trocholina spp., Coscinophragma cribrosum, ?Cuneolina scarsellai, Cuneolina camposauri, Cuneolina laurentii, Moesiloculina histri, Campanellula capuensis, miliolids and ostracods. This facies indicates an inner platform environment, which is a lateral equivalent to the coral and 


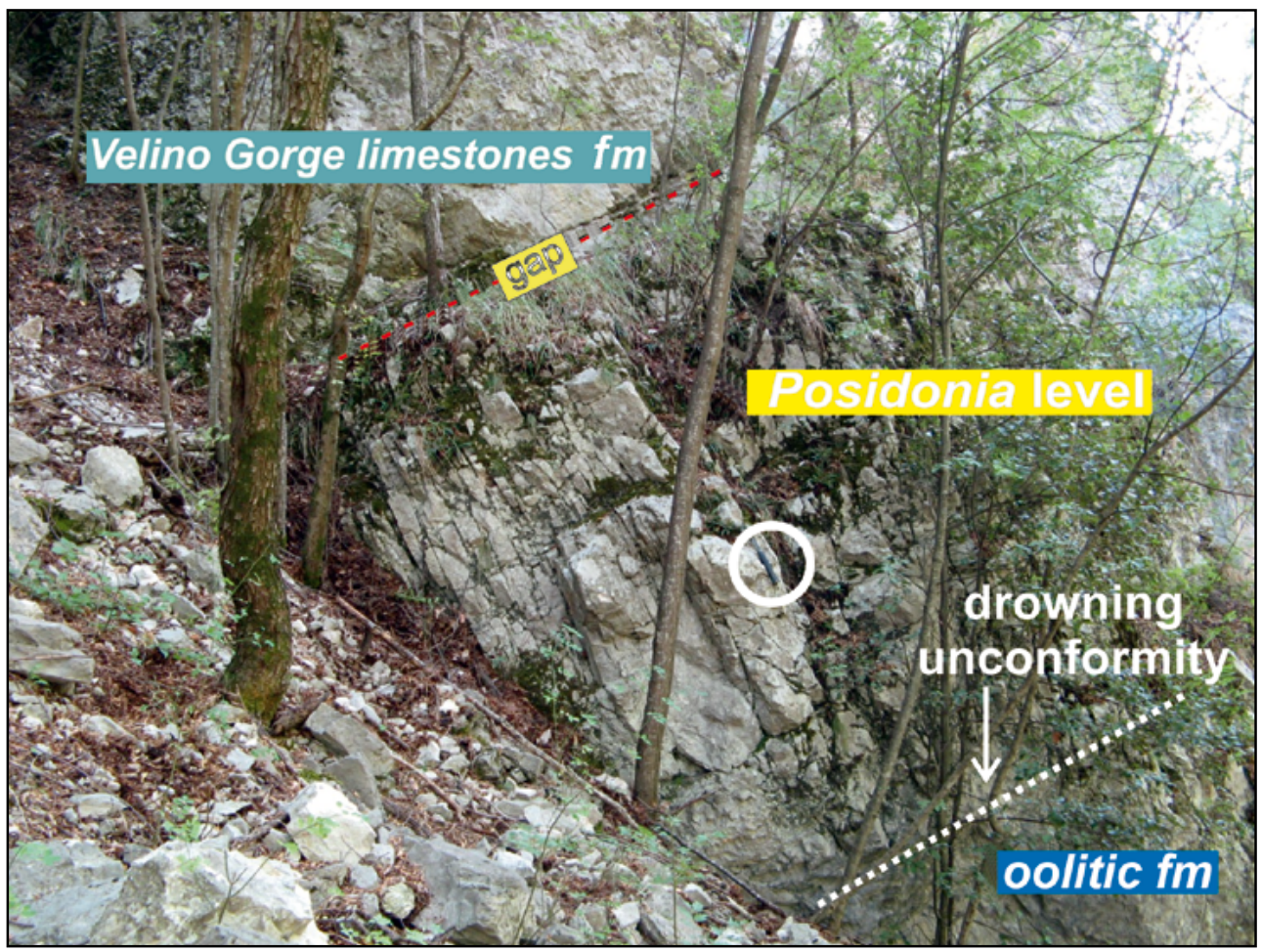

FIGURE 7. Palombara Section. Outcrop of the Posidonia level interposed between the underlying oolitic fm. (by a surface of drowning unconformity) and the overlying Velino Gorge limestones $\mathrm{fm}$. (by a paraconformity surface). The paraconformity highlights a $12 \mathrm{Ma}$ gap (from Bajocian p.p. to early Kimmeridgian p.p.). See circled hammer $(33 \mathrm{~cm})$ for scale.

diceratid limestones $\mathrm{fm}$. The thickness is about $500 \mathrm{~m}$ and the age is Berriasian-Barremian.

\section{Monte Nuria area}

To explain the peculiar features of the Jurassic units of the Monte Giano area, the exposures of the Monte Nuria area, located a few $\mathrm{km}$ to the south (Figs. 2; 3), have been taken as a reference for the Jurassic-Lower Cretaceous carbonate platform environments (Capotorti et al., 1995; Centamore and Dramis, 2010).

Based on literature data (Centamore and Dramis, 2010) and new sampling, we have partly reinterpreted two units of this succession. The calcareous-dolomitic $\mathrm{fm}$. is considered Aalenian-Oxfordian p.p. in age. However, given its reduced thickness compared to other more inner Latium-Abruzzi platform successions (e.g. Damiani et al., 1991a; Miccadei et al., 2014), and the remarkable absence of some fossil markers (e.g. Redmondoides primitivus, Redmondoides medius, Paleopfenderina salernitana), the late Bajocian-early Oxfordian interval is poorly recorded. These features are related to low sedimentation rates and possibly to repeated sedimentary hiatuses (Fig. 4). The coral and diceratid limestones fm., Kimmeridgian p.p.-Lower
Barremian in age (according to Centamore and Dramis, 2010), is here interpreted to be an inner to outer platform transitional facies, Kimmeridgian p.p.-Berriasian p.p. in age (Fig. 4), due to its stratigraphic position and fossil content. For these reasons, it is partly correlated with the nerineid and diceratid limestones fm. of Rusciadelli and Ricci (2013).

\section{THE EARLY BAJOCIAN TECTONIC PHASE AND ITS ROLE IN THE DEVELOPMENT OF THE MONTE GIANO PELAGIC CARBONATE PLATFORM}

\section{Platform drowning: a regional discussion}

The transition from inner and marginal shallow water carbonate platform deposits (calcareous-dolomitic and oolitic fms.) to pelagic deposits (Posidonia level, Fig. 4) represents a drowning unconformity (Schlager, 1989) and indicates a sudden drowning of the Monte Giano area in the early Bajocian (Figs. 7; 8). In order to explain this drowning process, we have to take into account eustasy, paleoceanography, tectonic activity and variations in sediment supply during the Middle Jurassic at regional and local scale. The main regional processes involved include the following: 


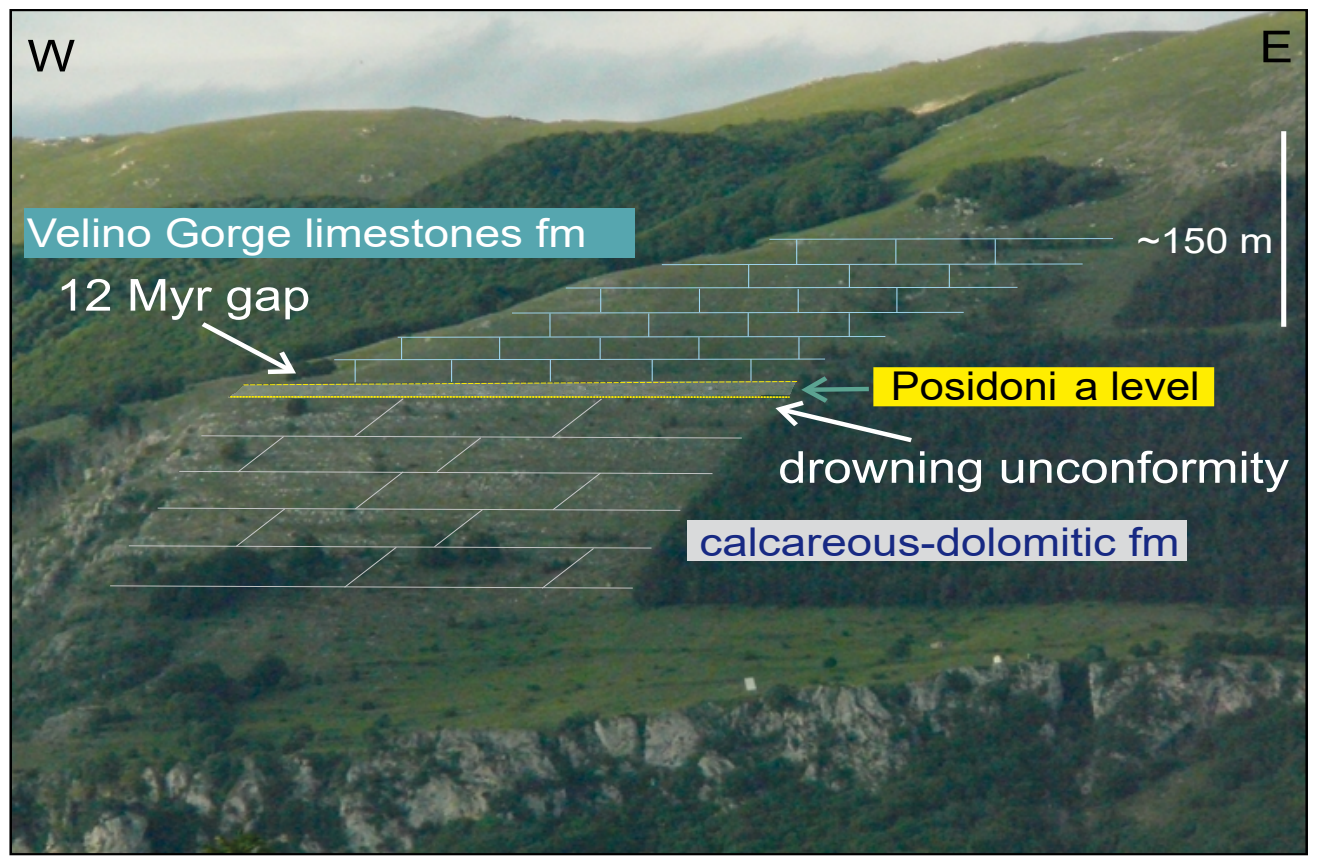

FIGURE 8. Croce di Monte Giano section. Panoramic view from South of the Middle-Upper Jurassic succession.

i) A relative sea-level rise at the late early Bajocian after a major sea-level fall recorded at the Aalenian-Bajocian boundary, as documented by the global sea-level curves (Haq, 2017).

ii) An important paleoceanographic event is recorded in the western Tethys realm: the onset of siliceous sedimentation at the early Bajocian, which persisted through a time span of $\sim 12 \mathrm{Ma}$ (until the end of the Oxfordian). This change to dominantly siliceous sedimentation is thought to indicate a crisis in the pelagic carbonate factory, as well as a crisis of the mud carbonate factory and/or a turnover of producers in the carbonate platform (Al-Mojel et al., 2018; Baumgartner, 1987; Colacicchi and Bigozzi, 1995; Cobianchi and Picotti, 2001; Morettini et al., 2002). This crisis in the carbonate production is related to a complex series of paleoceanographic, atmospheric and biological events: oceanic spreading of the western Tethys, prolonged volcanic activity, change in the chemical composition of the ocean waters and shallowing of carbonate compensation surfaces, increase of $\mathrm{CO}_{2}$ in the atmosphere, climatic variations, runoff of nutrients from continents and eutrophication (Cecca et al., 1990; Farinacci et al., 1981; Morettini et al., 2002). Positive excursions in the pelagic $\delta^{13} \mathrm{C}$ record, well documented in the Umbria-Marche Basin for this interval of geologic time, can correlate to episodes of platform drowning (Bartolini et al., 1996; Morettini et al., 2002), as the drowning, in the early Pliensbachian, of the fault-bounded small platforms created by the Sinemurian rift tectonics, and their conversion into PCPs
(Marino and Santantonio, 2010; Santantonio, 1993). This suggests the existence of a coupling mechanism between changes in the global carbon cycle and platform drowning (Föllmi et al., 1994).

Because of these global paleoceanographic events, a general phase of environmental stress affected the LatiumAbruzzi platform from the Bajocian p.p. to the OxfordianKimmeridgian, as testified by the widespread inner platform facies with monotonous successions of limestones and dolostones bearing an oligotypic fauna (Damiani et al., 1991b, 1998; Chiocchini et al., 1994), characterized by low sedimentation and subsidence rates (Colacicchi and Bigozzi, 1995). We must remark that the biostratigraphic attribution of this unit to the Bathonian-Callovian is not unequivocal on the basis of its fossil content.

iii) The last rifting phase in the Latium-Abruzzi platform is of Early Jurassic age. By contrast, in the neighbouring Umbria-Marche Basin a younger pulse of tectonic extension can be documented, although occurring during a passive-margin phase of widespread quiet postrift sedimentation. In fact, an extensional Bajocian episode was inferred by Galluzzo and Santantonio (2002) to explain three peculiar features on the Sabina Plateau, the largest PCP of the Sabina region (Figs. 1; 2): i) a lower Bajocian megabreccia resting on the paleoescarpment of the plateau, ii) coeval neptunian dykes at the plateau edge, and iii) presence of graded and laminated ooid-rich beds in the condensed pelagic succession on top of the Sabina 
Plateau. Galluzzo and Santantonio (2002) interpreted these occurrences as the result of a major episode of seismic instability in the region, triggering the fracturing, collapse and backstepping of the Sabina Plateau margin, and, at the opposite side of the Sabina sub-basin, the inception of giant turbidity flows. Ooid-rich megabeds in the Calcarie Marne a Posidonia Fm., onlapping the plateau margin, would be in this view a witness of the westwards-directed (in present-day coordinates) flows hitting the submarine escarpment, and continuing their journey by climbing it and scouring the plateau top, eventually discharging their load in the form of turbiditelike overbank deposits. In this regard, the Polino PCP (North of the town of Rieti, Fig. 2) has been interpreted as attesting a Bajocian episode of extension, which would have caused the downfaulting of part of the PCP and draping of the condensed succession by the basinal Calcari Diasprigni Fm. (Leonardi et al., 1997). Donatelli and Tramontana $(2010 ; 2012)$, investigating some of the most important PCPs of the Marche Region (M. AcutoCorno di Catria and Mt. Mura areas, Fig. 2), noticed that marginal portions of these PCPs were locally reactivated in the early Middle Jurassic. Cannata and Santantonio (2010) reported a tectonic retreat of the paleoescarpment, with the development of neptunian dykes, around the early-late Bajocian boundary at Corno di Catria (Fig. 2).
This Bajocian tectonic phase in the central-northern Apennines has been generally interpreted by the above mentioned authors as a generic renewal of the late Hettangian-early Sinemurian rifting phase. However, the actual geodynamic cause is a puzzling question if this early Bajocian episode took place about 30Ma after the main rifting phase (late Hettangian-early Sinemurian). Furthermore, this episode also postdated about $15 \mathrm{Ma}$ the final extensional phase (late Pliensbachian-Toarcian) that in the more internal paleogeographic domains closer to the regional spreading axis (western Alps, western Tuscany, paleo-Calabria), marks the breakup unconformity ("Rift 1 " and "Rift 2" in Santantonio and Carminati, 2011, and references therein). According to Carminati et al. (2013), a minor regional extensional stress field in this period was induced by the dehydration process of thick $(1.5-2 \mathrm{~km})$ Upper Triassic evaporites underlying the Hettangian-early Sinemurian carbonates (Calcare Massiccio Fm.), and lateral salt flow from the Latium-Abruzzi platform towards deeper-water domains (Umbria-Marche Basin). This flow was due to higher sedimentary loading in the carbonate platform areas, producing a pressure gradient towards the pelagic basin at the depth of the evaporites, superimposed over a minor regional extensional stress field accompanied by moderate regional subsidence. Alternatively, Bajocian tectonics in the central-northern Apennines could have

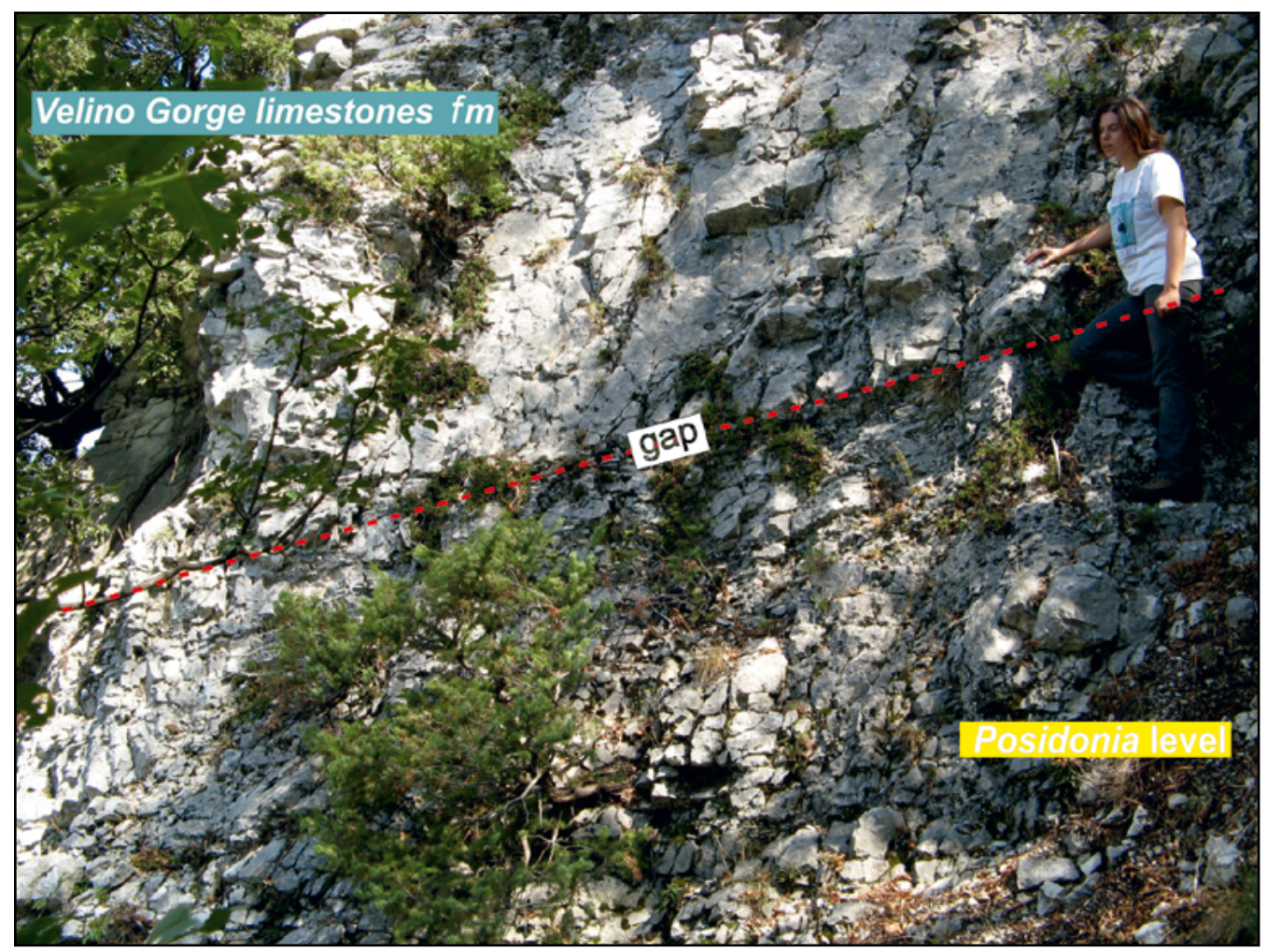

FIGURE 9. Mastro Domenico Section (see Fig. 3 for location). Paraconformity between the Posidonia level and the overlying Velino Gorge limestones fm. 
represented a far-field effect of the onset of spreading in the Piemont and Liguria oceans at $170 \mathrm{Ma}$, when the Alpine Tethys opened as a branch of the central Atlantic in response to sinistral transcurrent motion of Africa with respect to Europe (Handy et al., 2010).

\section{Platform drowning: local setting}

In order to address the causes of the drowning of the Monte Giano sector, additional local facts must be taken into consideration:

i) The drowning of the Monte Giano area was a local event because the neighbouring Latium-Abruzzi platform successions, exposed to the south and to the east, indicate persistent shallow-water carbonate sedimentation from the Jurassic to the Early Cretaceous, although sedimentary hiatuses can be detected in the Bajocian p.p.-Kimmeridgian p.p. time interval (Chiocchini et al., 1994). This is the case of the Jurassic succession of Monte Nuria, where low sedimentation rates and at least one omission surface are evidence of depositional hiatuses in the late Bajocian to early Oxfordian time (see above).

ii) The conformable contact between the Posidonia level and the underlying lower Bajocian p.p. inner (calcareousdolomitic fm.) and marginal (oolitic fm.) platform facies, as well as the paraconformable contact between the Posidonia level and the overlying Velino Gorge limestones fm. (Figs. 7; 8; 9), Kimmeridgian p.p. in age, indicate that this was not a high gradient slope environment until at least middle-Late Jurassic time. Before then, there is no evidence of angular unconformities or gravity flow deposition, or lateral facies transitions. Finally, the early Bajocian p.p.Kimmeridgian p.p. stratigraphic gap at Monte Giano could not conceivably be due to any abnormally long-lasting (12Ma) phase of bypass in a slope environment.

iii) The investigated succession exhibits at least two of the typical features of the PCPs scattered through the Umbria-Marche Basin: i) remarkable lack of chert, and ii) occurrence of globuligerinid foraminifers (Fig. 5C) in the Posidonia level (Fig. 4), plus the gap between the early Bajocian p.p. Posidonia level and the overlying Kimmeridgian p.p. Velino Gorge limestones fm.

iv) The Posidonia level covers about $60 \mathrm{~km}^{2}(7 \mathrm{~km}$ in the NS direction, $9 \mathrm{~km}$ in the EW direction, Fig. 3), with a very reduced thickness and with homogeneous sedimentological and paleontological features. Unfortunately, no outcrops documenting the lateral termination of this deposit are observed.

As a first interpretation of the above mentioned features, the absence of chert over a very wide area indicates that we are not dealing with a slope or basin environment, as chert is typically found in the Calcari e Marne a Posidonia Fm. of slope and hangingwall-block successions (Centamore et al., 1971). Globuligerinids have been found in intrabasinal highs of the Umbria-Marche Basin, whereas they are missing in the adjacent coeval basinal successions (Galluzzo and Santantonio, 2002, and references therein). Nonsedimentation from the Bajocian p.p. to the Kimmeridgian p.p. is one striking feature of all of the PCPs across the Umbria-Marche Basin (Fig. 10), representing a regional stratigraphic gap (Cecca et al., 1990; Santantonio, 1993; 1994; Santantonio et al., 2017). It is worthy of note that, unlike typical PCP successions, the Posidonia level has not strictly the sedimentological features of condensed deposits (Santantonio, 1993; 1994). In fact, except for the extremely reduced thickness, it lacks any cephalopod-rich facies and contains resedimented carbonate platform-derived material (Fig. 5C-D).

\section{Interpretation of the platform drowning and the creation of the Monte Giano PCP}

The paleoenvironmental changes occurred in the Bajocian, coupled with a high relative sea-level, certainly influenced carbonate production, but they cannot alone explain the drowning of only a limited sector of the LatiumAbruzzi platform (the Monte Giano area), apparently unrelated to any major lateral pelagic facies shift within a mappable regional transgressive trend.

Localized drowning, followed by a long period of sediment starvation, of a wide area that was part of a vast carbonate platform until the early Bajocian p.p. strongly suggests a tectonically driven drowning and rapid deepening. An early Bajocian extensional tectonic phase might have caused the fragmentation of this NW sector of the Latium-Abruzzi platform, leading to the formation of a local horst and graben architecture. Based on the lack of outcrops of Middle and Upper Jurassic deposits between Monte Giano and Monte Nuria, two possible Jurassic scenarios, with two different structural settings, can be considered (Fig. 11): i) an isolated large flat-topped PCP (Type 1 sensu Santantonio, 1994), separated from the Latium-Abruzzi platform by a presumably small and not very deep structural low; and ii) a downfaulted marginal step of the Latium-Abruzzi platform, at the hanging-wall of a north- dipping normal fault bounding the platform.

In the first hypothesis, the Monte Giano PCP would be bounded to the south by an antithetical fault of the major fault scarp that delimited the Latium-Abruzzi platform to the north, with of a narrow pelagic basin between them (Fig. 11). This basin was presumably not very deep since it would have been completely infilled with platform-derived material from early Bajocian to early Kimmeridgian time. To 
the north, this PCP would be separated from the Gran Sasso sub-basin by the (unexposed) ancestral paleogeographic divide, which had formed as a result of the late Hettangianearly Sinemurian rifting phase (Castellarin et al., 1978) (Figs. 1; 11). In this scenario, the anomalous occurrence of resedimented material inside the Posidonia level can be interpreted as the result of spill-over of turbidity currents, which is also consistent with the proximity of a productive (although with low sedimentation rates) sector of the Latium-Abruzzi platform, represented by the upper part of calcareous-dolomitic fm. of the Monte Nuria succession.

Considering its size, the Monte Giano PCP could in this interpretation be defined as a pelagic plateau, much like the Sabina Plateau (Galluzzo and Santantonio, 2002; Santantonio, 1994; Fig. 2). Its anomalous large size compared to other PCPs scattered through the UmbriaMarche Basin, could be linked to the extensional structural style. According to Santantonio and Carminati (2011), the Jurassic PCPs were generally small (few $\mathrm{km}^{2}$ ) and had an irregular shape as a result of the peculiar extensional geometries dictated by the varying thickness of the salt layer underlying the Upper Triassic-Lower Jurassic carbonates (Calcare Massiccio and Dolomia Principale Fms.): a thick salt layer would produce a thin-skinned system of closely spaced faults at shallow structural levels, decoupled from the basement due to salt behaving as a detachment level, while a thin salt layer could be crosscut by more evenly spaced faults rooted in the basement, producing a thick-skinned pattern (Santantonio and Carminati, 2011). Therefore, faults had deeper root levels wherever the salt layer was laterally replaced by dolostones, producing greater vertical offset, like in the Sabina Plateau, as opposed to splaying into a number of lower-displacement faults via a detachment layer. Because the Monte Giano area was located during the Jurassic and Cretaceous times in a transitional sector between the Latium-Abruzzi platform and adjacent pelagic basins, probably also corresponding to the transition between thick and thin layers of evaporites (Santantonio and Carminati, 2011), this model could explain the relative large size of the Monte Giano PCP.
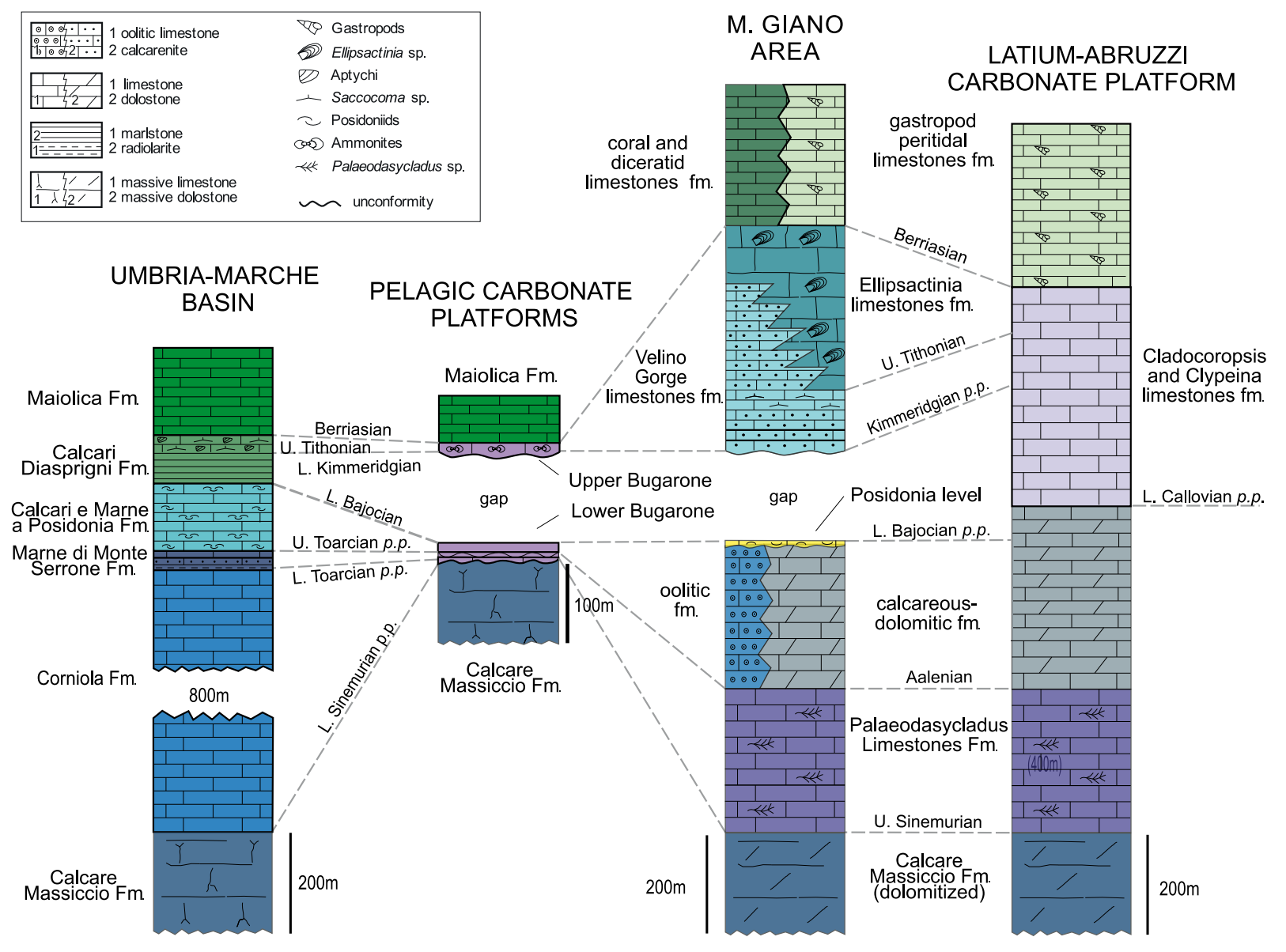

FIGURE 10. Time-stratigraphic correlation between the Monte Giano succession and the representative stratigraphic successions of the Umbria-Marche Basin (modified after Galluzzo and Santantonio, 2002), the pelagic carbonate platforms (modified after Galluzzo and Santantonio, 2002) and the Latium-Abruzzi carbonate platform (from Centamore and Dramis, 2010). 
In the second hypothesis, the Monte Giano structure would represent a downfaulted block located at the hanging-wall of a Bajocian normal fault scarp bounding the survived part of the Latium-Abruzzi platform (Fig. 11). The thickening polarity of the Posidonia level suggests a moderate southward tilting of this downfaulted block. A thick-skinned fault model would also apply for this alternative hypothesis. Rapid block tilting is envisaged as a possible cause of non-deposition (Santantonio et al., 1996), but not suitable in this case because the thickness of the Posidonia level only differs by $18 \mathrm{~m}$ in $7 \mathrm{~km}$ distance. It is very tricky to explain how a downfaulted block adjacent to the Latium-Abruzzi platform cannot receive any sediment for about $12 \mathrm{Ma}$ (late early Bajocian to early Kimmeridgian), also considering the starvation in carbonate sedimentation detected in the neighbouring Monte Nuria sector of the Latium-Abruzzi platform during the Bajocian p.p. Oxfordian p.p. time interval.

On the basis of the exposed considerations, we favor the first hypothesis. According to this interpretation, the Monte Giano structure would represent the south-easternmost PCP generated during the Jurassic, the only one formed within the Latium-Abruzzi platform domain, East of the presentday Olevano-Antrodoco-Sibillini thrust, that separates it from the Sabina sub-basin (Fig. 2). It should be remarked that the closer PCPs (Polino and Terminillo, Fig. 2) in the neighbouring Reatini mountains, about $10 \mathrm{~km}$ West of the
Monte Giano area, were buried during the Bajocian by the basinal Calcari e Marne a Posidonia Fm. (Fig. 10). This environmental change suggests that a large area comprising both the edge of the platform and the adjacent portion of the basin underwent a significant deepening due to the early Bajocian tectonic phase.

To explain this tectonic event occurred after the rifting phase of the western Tethys, recognized in a few PCPs of the Umbria-Marche Basin and, for the first time, in the LatiumAbruzzi platform, two main factors at different scales have to be considered. It is assumed that, in a general context of extensional tectonics related to the opening of the Piemont-Liguria Ocean, the regional rheologic difference between the two paleogeographic domains corresponding to the transition between thick and thin layers of Triassic evaporites, may have caused the formation of normal faults only within the basin and at the basin/carbonate platform boundary but not within the more internal sectors of the latter.

\section{LATE JURASSIC-EARLY CRETACEOUS EVOLUTION}

Following the pelagic interval (Posidonia level) that marks the drowning of the Monte Giano sector, and the long non-depositional time span, sedimentation was resumed at early Kimmeridgian time, with the fine-grained

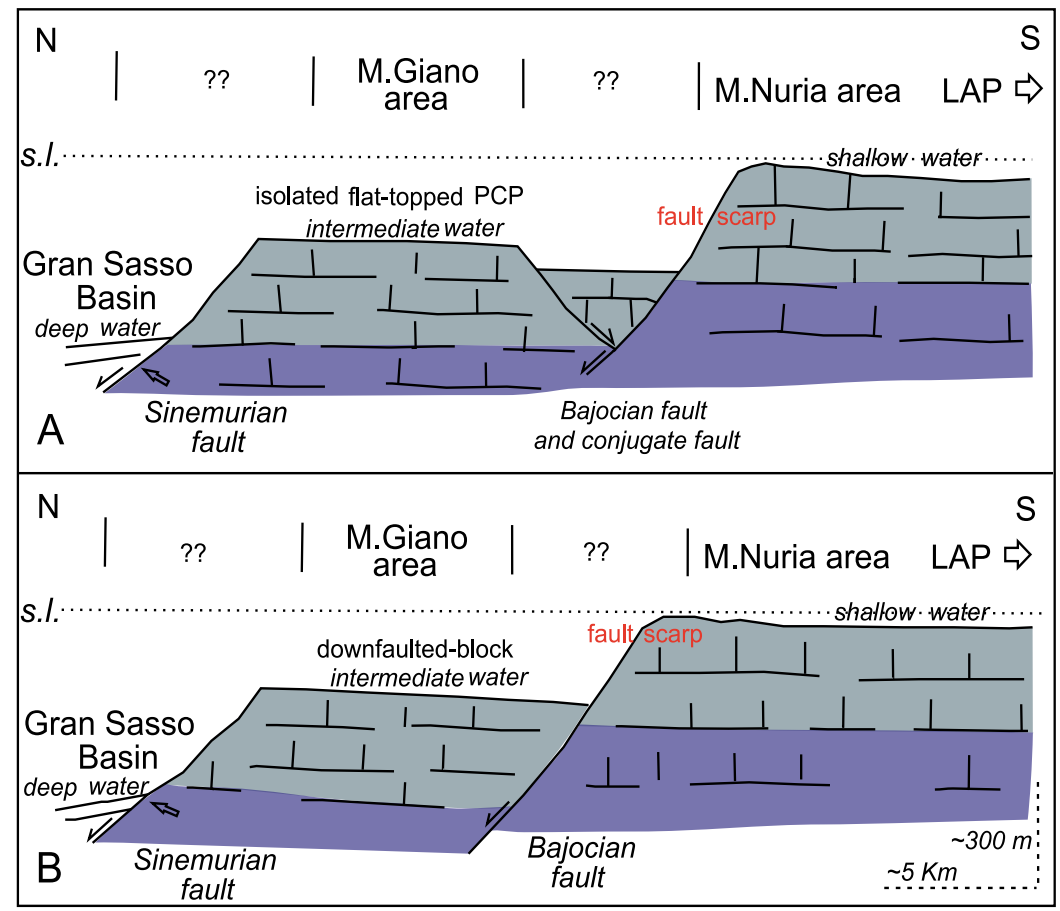

FIGURE 11. Cartoon showing the two different hypotheses of the geometry of the Bajocian Monte. Giano structure: A) PCP Type 1. B) Downfaulted block. The lithostratigraphic units are: the Palaeodasycladus limestones Fm. (purple) and the calcareous-dolomitic and oolitic fms. (grey). LAP stands for Latium-Abruzzi Platform. 
pelagic turbidites or wackestones of the base of Velino Gorge limestones fm. (Figs. 4; 12), fed by the neighbouring Latium-Abruzzi platform (Fig. 5E-F). Turbidites are related to a general recovery of healthy carbonate production throughout the Latium-Abruzzi platform due to the bloom of producers (Damiani et al., 1991b, 1998; Chiocchini et al., 1994), documented elsewhere in the central Apennines by broad platform rim/margin complexes (Rusciadelli and Ricci, 2013).

The lower part of Velino Gorge limestones fm. is made up of packstones-wackestones, also with rare chert (Viperelle Section, Figs. 4), representing a distal slope evolving upwards into a medium and proximal slope with coarser-grained facies. This unit is overlain by the bioclastic packstones to rudstones of the Upper Tithonian Ellipsactinia limestones fm. (Figs. 4; 5C-D). The remarkable thickness (up to $400 \mathrm{~m}$ ) of this unit and the lateral relationships northwards with slope deposits and southwards with inner platform facies, let us to propose the existence of largescale clinoform bodies. Poor outcrop conditions however make a direct observation of these geometries generally impossible, while pervasive diagenetic alteration can mask primary sedimentary structures. One notable exception is found at the Roccette Section (Fig. 13), where low-angle clinoform beds indicate northward progradation.

The Velino Gorge limestones and Ellipsactinia limestones fms. constitude a shallowing- and coarseningupward sequence and are partly lateral to each other along a South to North transect (Figs. 3; 4; 12). This testifies a gradual facies evolution from distal slope to proximal slope during the Kimmeridgian-early Tithonian interval (Velino Gorge limestones fm.) and from proximal slope to platform-margin reef complex during the late Tithonian (Ellipsactinia limestones fm.). The very thick (up to $600 \mathrm{~m}$ ) prograding slope bodies of the Ellipsactinia limestones $\mathrm{fm}$. are thought to represent Upper Jurassic marginal facies around the Latium-Abruzzi platform and the Apulian platforms, both at surface (Miccadei et al., 2014) and subsurface (Santantonio et al., 2013).

This evolution from distal to proximal facies during the whole Tithonian could be the result of a combination of two important factors: i) the geometry of the carbonate platform, which was not a rimmed platform with a marginal area gently dipping towards the basin (Rusciadelli and Ricci, 2013); and ii) the strong global regressive character of sedimentation (Gill et al., 2004; Hardenbol et al., 1998; Jacquin et al., 1998), with three prominent sea-level drops found in eustatic-cycle charts (Haq, 2017). Remarkably, the punctuated occurrence of deep-photic zooxanthellate corals in PCPs, in the Umbria-Marche Basin, related to these eustatic fluctuations in the Apennines was reported by Santantonio et al. (1996) and Gill et al. (2004).
The northward progradation trend in the Monte Giano area continued during the Berriasian, with the deposition of coarse-grained bioclastic, marginal facies of the coral and diceratid limestones fm. in the northern sector of the studied area (Palombara Section, Figs. 3; 4; 12), and with the transitional to inner platform facies of the gastropod peritidal limestones fm. in the central-southern area (Figs. $3 ; 4 ; 12)$. The wide platform-edge/upper margin sector of the Late Jurassic time narrowed during the Cretaceous, evidencing an important change in the carbonate producers and consequently in the carbonate platform physiography (Scott, 1988).

\section{PALEOBATHYMETRY AND EVALUATION OF VERTICAL DISPLACEMENT ALONG EARLY BAJOCIAN FAULTS}

The field-data collected in the Monte Giano area, and the correlation of this area with the Monte Nuria area, enable us to evaluate the possible vertical separation along the early Bajocian faults and consequently the paleobathymetry of the PCP.

The offset of the Bajocian northwards dipping master fault must have resulted in a scarpment between the edge of the NW sector of the persistent Latium-Abruzzi platform (Monte Nuria) and the Monte Giano PCP-top. The vertical separation can be calculated by taking into account the following parameters: i) the thickness of the slope-to-outer platform reef complex regressive deposits (Velino Gorge limestone and Ellipsactinia limestone fms.), as measured in the Monte Giano sections (Fig. 4); ii) the thickness of the coeval inner platform and platform margin reef complex sediments of the Monte Nuria area (the upper part of the calcareous-dolomitic fm., the echinoderm and coral limestones fm and the lower-medium part of the coral and diceratids limestones fm.); and iii) the different compaction rates of slope and marginal carbonate platform sediments.

According to Galluzzo and Santantonio (2002), the minimum offset of the early Sinemurian faults bounding the PCPs in the Umbria-Marche Basin is constrained by the original thickness (uncompacted) of the basin-fill Corniola to lower Maiolica succession, assuming that the submarine rift topography would have been generally levelled by early Cretaceous time (Centamore et al., 1971; Farinacci et al., 1981). These authors also assume very slow rates of subsidence of the PCP/basin system during the Middle and Late Jurassic, based on field geometries (paleoescarpment analysis; Carminati and Santantonio, 2005) and locally on coral paleoecology (Carminati et al., 2013; Farinacci et al., 1981; Galluzzo and Santantonio, 2002; Gill et al., 2004). In our case, the subsidence of the Monte Giano PCP during the Middle-Late Jurassic must have been comparable with that of the neighbouring Latium-Abruzzi platform (Monte 


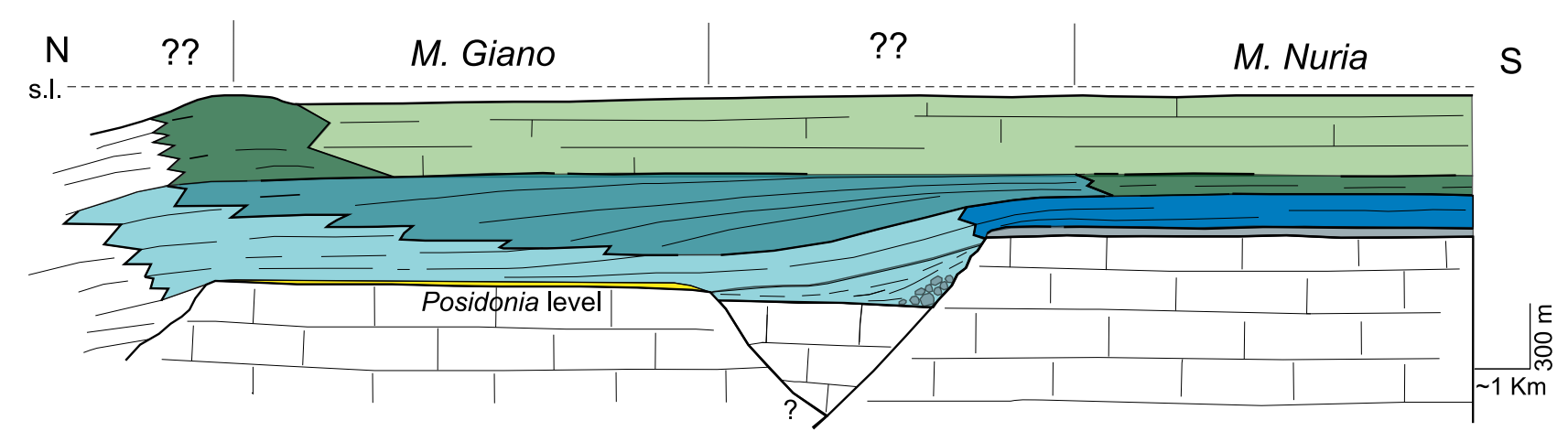

\section{Early Cretaceous}

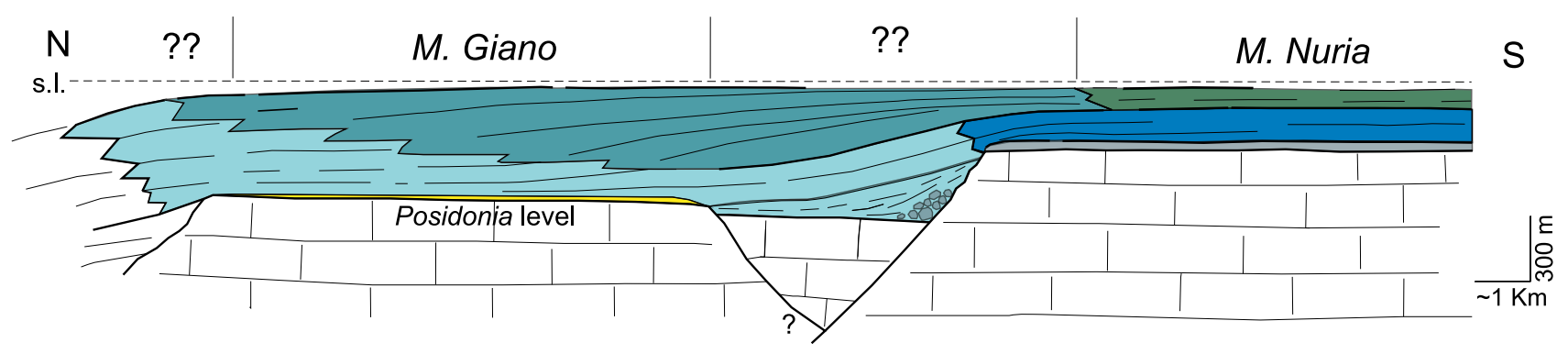

Upper Tithonian

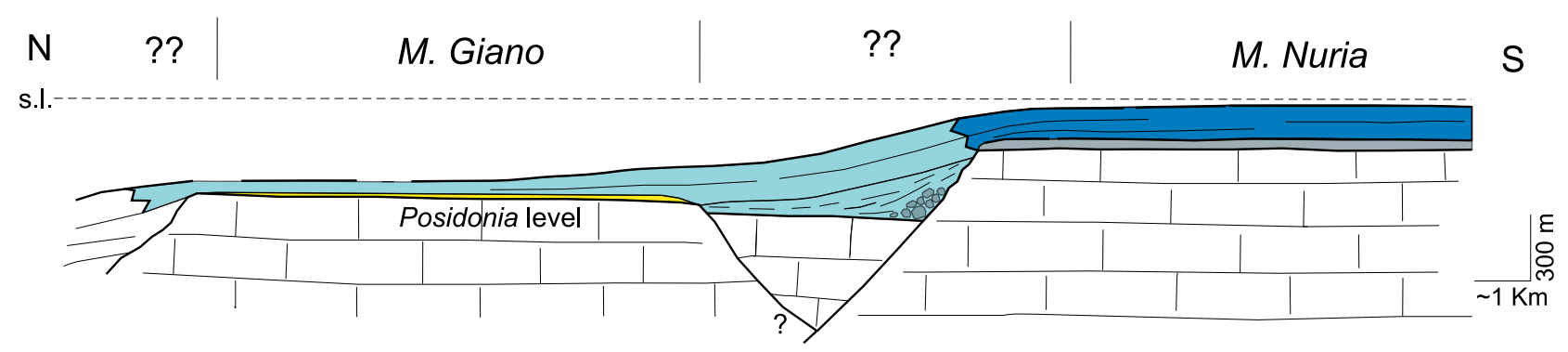

Early Kimmeridgian p.p.-Early Tithonian

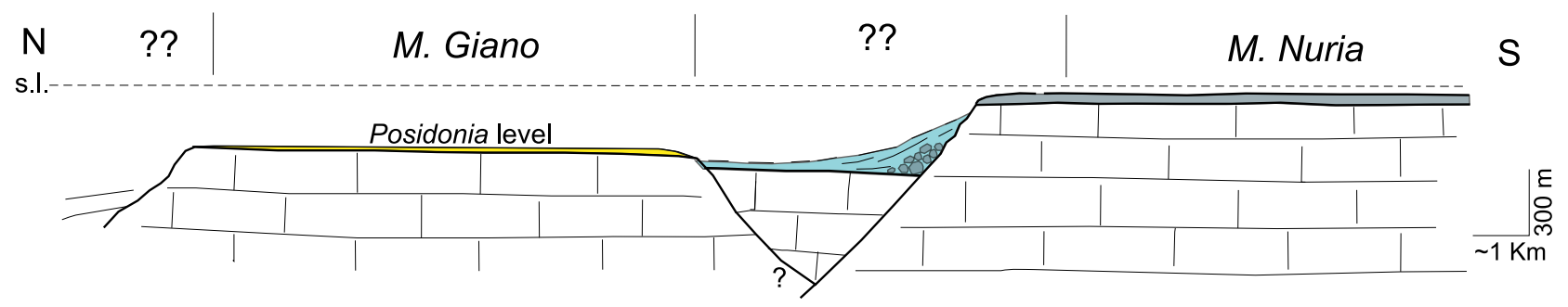

\section{Early Bajocian p.p.-Callovian p.p.}

calcareous-

FIGURE 12. Cartoon showing the evolution of the NW sector of the Latium-Abruzzi platform (Monte Nuria area) from the early Bajocian p.p. to the Early Cretaceous p.p., considering the Monte Giano area a pelagic carbonate platform. 
Nuria), which is considered to have been greater than that of the more distal parts of the Umbria-Marche Basin (Carminati et al., 2013).

The early Bajocian p.p. to Tithonian Monte Nuria succession has a thickness of about 300m (Fig. 4) and is dominated by bioclastic shallow water facies (mostly grainstones-rudstones) with rare intercalations of packstones-wackestones (mainly in the lower 50m). Such coarse-grained clast-supported platform carbonates are commonly subjected to early cementation. For these reasons compaction is considered negligible in our estimates. We must note that: i) for shallow marine carbonates, section thickness is considered equal to the accommodation space (=subsidence + sea-level) available in a given time interval, since the limit for sediment aggradation is the sea/air interface; and ii) as the $300 \mathrm{~m}$-thick Monte Nuria succession embeds some hiatuses or low deposition periods, the availability of accommodation space must have been intermittent during the stratigraphic interval under consideration.

The Monte Giano succession has a total thickness of about 500m for the same time interval (Fig. 10). Despite the dominance of bioclastic sediments, we assume that during progressive burial of sediments in a subsiding basin/ slope environment some degree of compaction occurred, because this process is mainly depth dependent rather than time dependent (Carminati et al., 2013). We assume that this compaction did not exceed 50m (see Berra and Carminati, 2012 and references therein).

Based on the above assumptions, the Velino Gorge limestones-Ellipsactinia limestones succession documents the filling history of the accommodation space produced by the early Bajocian extension, which occurred through an Upper Jurassic shallowing-upwards mega-sequence.

The offset of the early Bajocian master fault can be derived from the difference between the uncompacted thickness $(\sim 550 \mathrm{~m})$ of the Monte Giano deposits and that of the Monte Nuria platform succession (300m) for the Middle-Late Jurassic time interval. This difference is approximately $250 \mathrm{~m}$, but considering the $\mathrm{PCP} /$ basin couplet, a somewhat larger displacement (we infer that not more than $50-100 \mathrm{~m}$, as there is no evidence of any deep basin deposit) would be required in order to accommodate graben subsidence (Figs. 11; 12).

The same value (about $250 \mathrm{~m}$ ) would obviously also correspond to the paleodepth of the Monte Giano area after the early Bajocian tectonic phase (Posidonia level) and throughout the time span covered by the hiatus (until

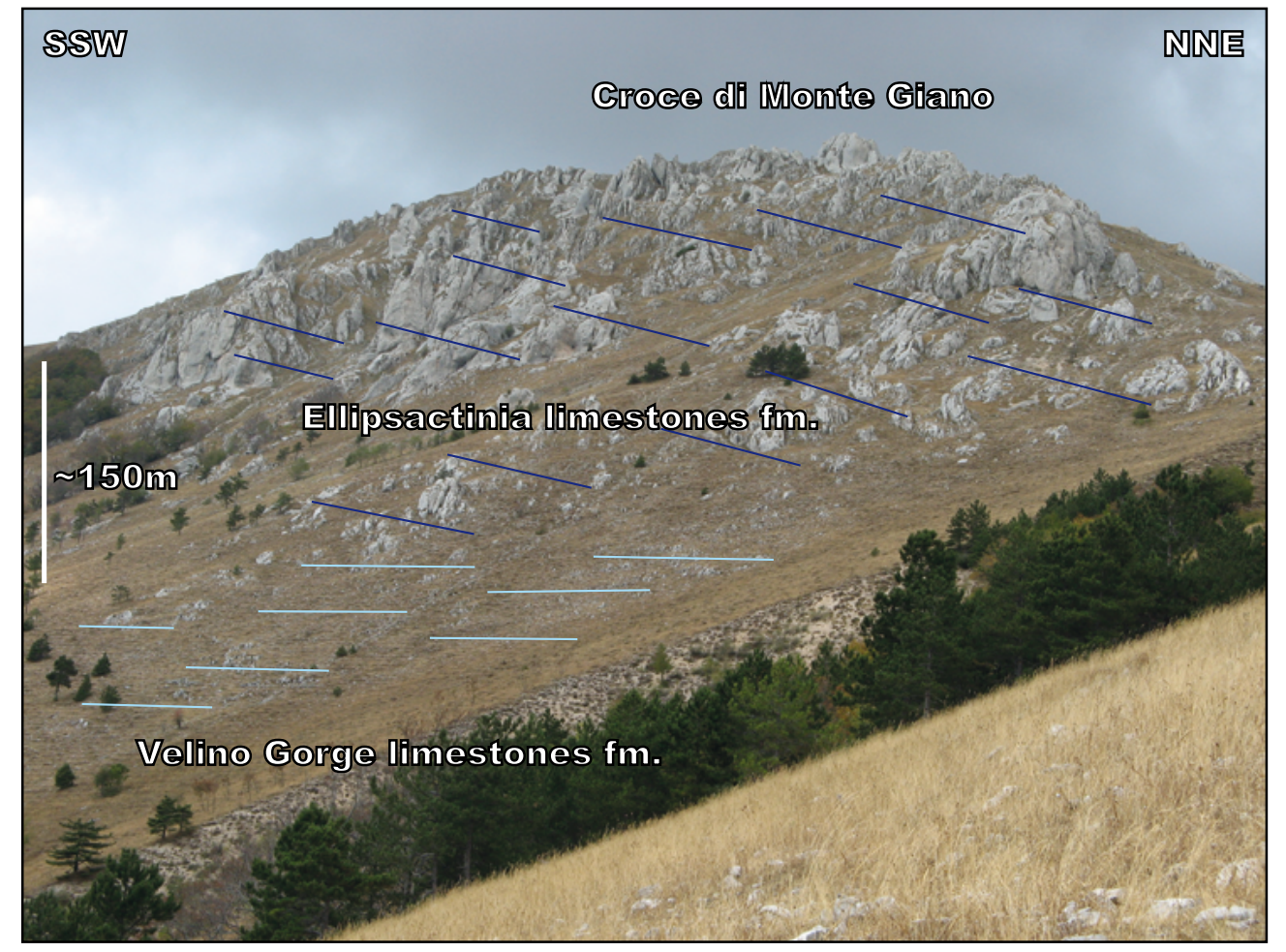

FIGURE 13. Roccette section (see Fig. 3 for location). Panoramic view from SE of Croce di Monte Giano M., showing the upper part of the Velino Gorge limestones $\mathrm{fm}$. and the base of the Ellipsactinia limestones $\mathrm{fm}$. with low angle clinoforms indicating progradation toward the North. 
the early Kimmeridgian p.p.), decreasing to $0 \mathrm{~m}$ with progradation of the Kimmeridgian-Tithonian slope/ platform system.

\section{CONCLUSIONS}

The studied Monte Giano area has been traditionally considered a persistent shallow water environment of the north-western sector of the Latium-Abruzzi platform facing the Umbria-Marche Basin. Detailed geological mapping, sedimentological and biostratigraphic studies lead us to propose a new interpretation of the tectonic and stratigraphic evolution of the Latium-Abruzzi platform/Umbria-Marche Basin transition during the Middle Jurassic-Early Cretaceous time interval. This new interpretation represents a radical departure from earlier assumptions.

Shallow-water sedimentation started in the area in the Late Triassic and persisted until the early Bajocian p.p., when an extensional tectonic phase caused the breakup and drowning of this sector of the Latium-Abruzzi platform. This post-rift tectonic phase is documented by the drowning unconformity surface separating the carbonate platform formations from the overlying thin (4-22m) pelagic Posidonia level, early Bajocian p.p. in age. This unconformity documents the sudden drowning that affected the margin and part of the inner area of the Latium-Abruzzi platform, while shallow water sedimentation persisted in more internal sectors of the platform, located to the south and southeast.

The early Bajocian tectonic phase created an "intermediate" paleogeographic compartment, lying at depths shallower than the Sabina and Gran Sasso subbasins but deeper than the more internal persistent LatiumAbruzzi platform (Figs. 1; 11; 12). This new structural area has been referred to as an isolated large flat-topped PCP (Type 1 sensu Santantonio, 1994) separated from the rest of the Latium-Abruzzi platform by a narrow basin.

Following the deposition of the Posidonia level, a $12 \mathrm{Ma}$ gap, ranging from the early Bajocian p.p. to the Kimmeridgian p.p., is documented all across the study area, in analogy with the well-known and studied UmbriaMarche PCPs.

The submarine relief created by the offset along the early Bajocian extensional master fault separating the Monte Nuria (representing the temporary north-westernmost sector of the Latium-Abruzzi platform) from the Monte Giano PCP was filled during the Late Jurassic, firstly with bioclastic sediments sourced from the persistent LatiumAbruzzi platform with minor pelagic input, and finally with the deposits of the platform itself. These sediments document the Kimmeridgian to Upper Tithonian northward migration from distal slope to marginal reef environment, to the point that the Monte Giano area was "re-conquered" by the Latium-Abruzzi platform $\sim 25 \mathrm{Ma}$ after its drowning. The northward progradation of the Latium-Abruzzi platform continued at Berriasian time with the deposition of marginal facies (coral and diceratid limestones fm.) in the northern sector of the study area, and inner platform facies, (gastropod peritidal limestones fm.) in the centralsouthern part.

The scale of the early Bajocian tectonic vertical displacement has been estimated, quantifying both the amount of vertical separation along the early Bajocian master fault (about 300-350m) and the paleobathymetry $(\sim 250 \mathrm{~m})$ of the Monte Giano PCP. Thus, an early Bajocian post-rift extensional tectonic phase has been detected in the Latium-Abruzzi platform. This tectonic event might be related to a general context of extensional tectonics due to the opening of the Piemont-Liguria Ocean, associated at regional scale with the difference in thickness of Triassic evaporites. These coupling factors caused the development of normal faults with modest vertical displacement at the basin and the basin/carbonate platform boundary.

\section{ACKNOWLEDGMENTS}

The authors would like to sincerely acknowledge Dr. Maurizio Marino for his help during field work, Drs. Rita Maria Pichezzi and Prof. Maurizio Chiocchini for their essential help with the micropaleontological analysis, and kindly thank Prof. Massimo Santantonio for fruitful discussions.

\section{REFERENCES}

Adamoli, L., Bigozzi, A., Ciarapica, G., Cirilli, S., Passeri, L., Romano, A., Venturi, F, 1990. Upper Triassic bituminous facies and Hettangian pelagic facies in the Gran Sasso range. Bollettino della Società Geolica Italiana, 109, 219-230.

Al-Mojel, A., Dera, G., Razin, P., Le Nindre, Y.M., 2018. Carbon and oxygen isotope stratigraphy of Jurassic platform carbonates from Saudi Arabia: Implications for diagenesis, correlations and global paleoenvironmental changes. Palaeogeography, Palaeoclimatology, Palaeoecology, 511, 388-402.

Bartolini, A., Baumgartner, P.O., Hunziker, J.C., 1996. Middle and Late Jurassic carbon stable-isotope stratigraphy and radiolarite sedimentation of the Umbria-Marche Basin (Central Italy). Eclogae Geologicae Helvetiae, 89, 811-844.

Baumgartner, P.O., 1987. Age and genesis of Tethyan Jurassic radiolarites. Eclogae Geologicae Helvetiae, 80, 831-879.

Bernoulli, D., 1967. Probleme der Sedimentation im Jura Westgriechenlands und des zentralen Appennin. 
Verhandlungen der Naturforschenden Gesellschaft in Basel, 78(1), 35-54.

Bernoulli, D., 1971. Redeposited pelagic sediments in the Jurassic of the central mediterranean area. Annales Instituti Geologici Publici Hungarici, 54, 71-90.

Berra, F, Carminati, E., 2012. Differential compaction and early rock fracturing in high-relief carbonate platforms: numerical modelling of a Triassic case study (Esino Limestone, Central Southern Alps, Italy). Basin Research, 24, 598-614.

Bice, D.M., Stewart, K.G., 1990. The formation and drowning of isolated carbonate seamounts: tectonic and ecological controls in the northern Apennines. In: Tucker, M.E., Wilson, J.L., Crevello, P.D., Sarg, J.F., Read J.F (eds.). Carbonate platforms, facies, sequences and evolution. International Association of Sedimentologists, 9 (Special Publication), 145-168.

Boccaletti, M., Calamita, F, Deiana, G., Gelati, R., Massari, F, Moratti, G., Ricci Lucchi, F., 1990. Migrating foredeep-thrust belt systems in the northern Apennines and Southern Alps. Palaeogeography, Palaeoclimatology, Palaeoecology, 77, 41-50.

Bombardiere, L., 1993. Analisi sedimentologica ed ultrastrutturale del fango carbonatico della Corniola dei massicci perugini (Umbria Occidentale) e di alcune sezioni dell'area umbromarchigiana. Palaeopelagos, 3, 113-125.

Calamita, F., Deiana, G., Invernizzi, C., Mastrovincenzo, S., 1987. Analisi strutturale della linea Ancona-Anzio tra Cittareale e Micigliano (Rieti). Bollettino della Società Geologica Italiana, 106, 365-375.

Calamita, F., Deiana, G., 1988. The arcuate shape of the UmbriaMarche-Sabina Apennines (Central Italy). Tectonophysics, 146, 139-147.

Calamita, F., Paltrinieri, W., Pelorosso, M., Scisciani, V., Tavarnelli, E., 2003. Inherited Mesozoic architecture of the Adria continental paleomargin in the Neogene Central Apennines orogenic system, Italy. Bollettino della Società Geologica Italiana, 122, 306-318.

Cannata, D., Santantonio, M., 2010. Jurassic paleogeography and Neogene faulting at Corno di Catria (Marche, northern Apennines). Rendiconti Online Società Geologica Italiana, $11,721-722$.

Capotorti, F, Centamore, E., Chiocchini, M., Civitelli, G., Corda, L., Mancinelli, A., Mariotti, G., Romano, G., Salvucci, R., 1991. Dati preliminari geologico-stratigrafici sull'unità di Monte Giano e Monte Gabbia. Studi Geologici Camerti, Volume Speciale 1991/2, 119-123.

Capotorti, F., 1993. Sedimentazione e deformazioni di un settore annegato di piattaforma carbonatica: l'evoluzione geologica dello spigolo nord-occidentale della piattaforma lazialeabruzzese. Tesi di dottorato. Roma, Università di Roma "La Sapienza", inedita, 256pp.

Capotorti, F., Fumanti, F, Mariotti, G., 1995. Evoluzione tettonicosedimentaria e strutturazione del settore di piattaforma carbonatica laziale-abruzzese nell'alta Valle del fiume Velino. Studi Geologici Camerti, Volume Speciale 1995/2, 101-111.

Carmignani, L., Kligfield, R., 1990. Crustal extension in the northern Apennines: the transition from compression to extension in the Alpi Apuane core complex. Tectonics, 9, 1275-1303.

Carminati, E., Santantonio, M., 2005. Control of differential compaction on the geometry of sediments onlapping paleoescarpments: Insights from field geology (Central Apennines, Italy) and numerical modeling. Geology, 33, 353-356.

Carminati, E., Lustrino, M., Doglioni, C., 2012. Geodynamic evolution of the central and western Mediterranean: tectonics vs. igneous petrology constraints. Tectonophysics, 579, 173-192.

Carminati, E., Corda, L., Mariotti, G., Scifoni, A., Trippetta, F., 2013. Mesozoic syn- and postrifting evolution of the Central Apennines, Italy: the role of Triassic evaporites. Journal of Geology, 121, 327-354.

Castellarin, A., Colacicchi, R., Praturlon, A., 1978. Fasi distensive, trascorrenze e sovrascorrimenti lungo la "Linea AnconaAnzio", dal Lias medio al Pliocene. Geologica Romana, 17, 161-189.

Cavinato, G.P., Salvini, F, Tozzi, M., 1986. Evoluzione strutturale del settore centrale della linea Olevano-Antrodoco. Memorie della Società Geologica Italiana, 35, 591-601.

Cecca, F, Cresta, S., Pallini, G., Santantonio, M., 1990. Il Giurassico di Monte Nerone (Appennino marchigiano, Italia Centrale): biostratigrafia, litostratigrafia ed evoluzione paleogeografica. Pergola 1987, Atti del II Convegno Internazionale "Fossili, Evoluzione, Ambiente", 63-139.

Centamore, E., Chiocchini, M., Deiana, G., Micarelli, A., Pieruccini, U., 1971. Contributo alla conoscenza del Giurassico dell'Appennino Umbro-Marchigiano. Studi Geologici Camerti, 1, 7-89.

Centamore, E., Adamoli, L., Berti, D., Bigi, G., Bigi, S., Casnedi, R., Cantalamessa, G., Fumanti, F, Morelli, C., Micarelli, A., Ridolfi, M., Salvucci, R., 1991a. Carta geologica dei bacini della Laga e del Cellino e dei rilievi carbonatici circostanti (Marche meridionali, Lazio nord-orientale, Abruzzo settentrionale). Studi Geologici Camerti, Volume Speciale 1991/2.

Centamore, E., Civitelli, G., Corda, L., Mariotti, G., Romano, A., Capotorti, F., Salvucci, R., Chiocchini, M., Mancinelli, A., 1991b. Carta geologica dell'area di M. Giano-M. GabbiaGole del Velino (alta valle del F Velino, Lazio nord-orientale). Studi Geologici Camerti, Volume Speciale 1991/2.

Centamore, E., Dramis, F,, 2010. Note Illustrative della Carta Geologica d'Italia alla scala 1:50.000, Foglio 358 "Pescorocchiano". Roma, Istituto Superiore per la Protezione e la Ricerca Ambientale (ISPRA) - Servizio Geologico d'Italia, 147pp.

Chiocchini, M., Farinacci, A., Mancinelli, A., Molinari, V., Potetti, M., 1994. Biostratigrafia a foraminiferi, dasicladali e calpionelle delle successioni carbonatiche mesozoiche dell'Appennino centrale (Italia). Studi Geologici Camerti, Volume Speciale 1994, 9-129.

Ciarapica, G., Passeri, L., 1998. Evoluzione paleogeografica degli Appennini. Atti ticinensi di scienze della terra, 40, 233-290. 
Ciarapica, G., Passeri, L., 2002. The palaeogeographic duplicity of the Apennines. Bollettino della Società Geologica Italiana, 1 (Volume Speciale), 67-75.

Ciarapica, G., Passeri, L., 2005. Late Triassic and Early Jurassic sedimentary evolution of the Northern Apennines: An overview. Bollettino della Società Geologica Italiana, 124, 189-201.

Ciarapica, G., 2007. Regional and global changes around the Triassic-Jurassic boundary reflected in the late NorianHettangian history of the Apenninic basins. Palaeogeography, Palaeoclimatology, Palaeoecology, 244, 34-51.

Cobianchi, M., Picotti, V., 2001. Sedimentary and biological response to sea-level and palaeoceanographic changes of a Lower-Middle Jurassic Tethyan platform margin (Southern Alps, Italy). Palaeogeography, Palaeoclimatology, Palaeoecology, 169, 219-244.

Cohen, K.M., Finney, S.C., Gibbard, P.L., Fan, J.X., 2013, updated. The ICS international chronostratigraphic Chart V 2018/08. Episodes, 36, 199-204.

Colacicchi, R., Bigozzi, A., 1995. Event stratigraphy and carbonate platform-basin interrelations during the Jurassic in the Central Apennines. Palaeopelagos, 5, 111-128.

Coli, M., 1981. Studio strutturale della "Linea Ancona-Anzio" tra Posta ed Antrodoco (Gole del Velino). Bollettino della Società Geologica Italiana, 100, 171-182.

Conti, M.A., Monari, S., 1992. Thin-shelled bivalves from the Jurassic Rosso Ammonitico and Calcari a Posidonia Formations of the Umbrian-Marchean Apennine (central Italy). Paleopelagos, 2, 193-213.

Damiani, A.V., Catenacci, V., Molinari, V., Pichezzi, R.M., 1991a. Lito-biofacies del Triassico superiore-Dogger nei Monti Simbruini e nei Monti Ernici (Lazio). Studi Geologici Camerti, Volume Speciale 1991/2, 181-186.

Damiani, A.V., Chiocchini, M., Colacicchi, R., Mariotti, G., Parotto, M., Passeri, L., Praturlon, A., 1991b. Elementi litostratigrafici per una sintesi delle facies carbonatiche mesocenozoiche dell'Appennino centrale. Studi Geologici Camerti, Volume Speciale, 1991/2, 187-213.

Damiani, A.V., Catenacci, V., Molinari, V., Panseri, C., Tilia, A., 1998. Note Illustrative della Carta Geologica d'Italia alla scala 1: 50.000, F 376 “Subiaco”. Roma, Servizio Geologico d'Italia, 55pp.

Dela Pierre, F, 1994. Stratigrafia della successione cretacicopaleogenica affiorante tra la valle del Velino e la valle dell'Aterno (Appennino centrale). Atti ticinensi di scienze della terra, 2 (Serie Speciale), 119-130.

Devoto, G., Praturlon, A., 1973. L'Appennino centrale. Atti Convegno Moderne vedute sulla Geologia dell'Appennino, Accademia Nazionale dei Lincei Q, 183pp.

Di Domenica, A., Turtù, A., Satolli, S., Calamita, F, 2012. Relationships between thrusts and normal faults in curved belts: new insight in the inversion tectonics of the CentralNorthern Apennines (Italy). Journal of Structural Geology, 42, 104-117.

Di Francesco, L., Fabbi, S., Santantonio, M., Bigi, S., Poblet, J., 2010. Contribution of different kinematic models and a complex Jurassic stratigraphy in the construction of a forward model for the Montagna dei Fiori fault-related fold (Central Apennines, Italy). Geological Journal, 45, 489-505.

Doglioni, C., 1991. A proposal of kinematic modelling for W-dipping subductions - possible applications to the Tyrrhenian-Apennines system. Terra Nova, 3, 423-434.

Donatelli, U., Tramontana, M., 2010. The Castellaccio Jurassic composite succession (Mt. Mura area, Umbria-Marche Apennines): preliminary palaeogeographic and palaetectonic considerations. Geoacta, 3 (Special Volume), 45-56.

Donatelli, U., Tramontana, M., 2012. Jurassic carbonate depositional systems of the Mt. Catria-Mt. Acuto area (Umbria-Marche Apennines, Italy). Italian Journal of Geosciences, 131, 3-18.

Farinacci, A., 1967. La serie Giurassico-Neocomiana di Monte Lacerone (Sabina). Nuove vedute sull'interpretazione paleogeografica delle aree di facies umbro-marchigiana. Geologica Romana, 6, 421-480.

Farinacci, A., Mariotti, N., Nicosia, U., Pallini, G., Schiavinotto, F, Elmi, S., 1981. Jurassic sediments in the Umbro-Marchean Apennines: an alternative model. In: Farinacci, A., Elmi, S. (eds.). Rosso Ammonitico Symposium Proceedings. Edizioni Tecnoscienza Roma, 335-398.

Farrimond, P., Eglinton, G., Brassel, S.C., Jenkyns, H.C., 1990. The Cenomanian-Turonian anoxic event in Europe: an organical geochemical study. Marine and Petroleum Geology, 7, 75-89.

Föllmi, K.B., Weissert, H., Bisping, M., Funk, H., 1994. Posphogenesis, carbone-isotope stratigraphy, and carbonateplatform evolution along the Lower Cretaceous northern Tethyan margin. Geological Society of America Bulletin, 106, 729-746.

Funiciello, R., Parotto, M., Praturlon, A., 1980. Carta tettonica d'Italia. Consiglio Nazionale delle Ricerche, "Progetto Finalizzato. Geodinamica".

Galluzzo, F., Santantonio, M., 2002. The Sabina Plateau: a new element in the Mesozoic palaeogeography of Central Apennines. Bollettino della Società Geologica Italiana, 1 (Volume Speciale), 561-588.

Gill, G.A., Santantonio, M., Lathuilière, B., 2004. The depth of pelagic deposits in the Tethyan Jurassic and the use of corals: an example from the Apennines. Sedimentary Geology, 166, 311-334.

Gueguen, E., Doglioni, C., Fernandez, M., 1997. Lithospheric boudinage in the Western Mediterranean back-arc basins. Terra Nova, 9, 184-187.

Handy, M.R., Schmid, S.M., Bousquet, R., Kissling, E., Bernoulli, D., 2010. Reconciling plate-tectonic reconstructions of Alpine Tethys with the geological-geophysical record of spreading and subduction in the Alps. Earth-Science Reviews, 102, 121-158.

Haq, B.U., 2017. Jurassic sea-level variations: a reappraisal. Geological Society of America Today, 28(1), 4-10.

Jacquin, T., Dardeau, G., Durlet, C., De Graciansky, P.C., Hantzpergue, P., 1998. The North Sea cycle: an overview of 2nd order transgressive/regressive cycles in western Europe. In: De Graciansky, P.C., Hardenbol, J., Jacquin, T., Vail P.R. 
(eds.). "Mesozoic and Cenozoic Sequence Stratigraphy of European Basins". Society of Economic Paleontologists and Mineralogists (SEPM), 60 (Special Publication), 445-466.

Leonardi, R., Lipparini, L., Nicosia, U., Ursini, F, Varazi, F., 1997. A peculiar type of Jurassic slope in the Polino area (Terni, Central Italy). Palaepelagos, 7, 145-168.

Manatschal, G., Bernoulli, D., 1998. Rifting and early evolution of ancient ocean basins: The record of the Mesozoic Tethys and of the Galicia-Newfoundland margins. Marine Geophysical Researches, 20, 371-381.

Marino, M., Santantonio, M., 2010. Understanding the geological record of carbonate platform drowning across rifted Tethyan margins: examples from the Lower Jurassic of the Apennines and Sicily (Italy). Sedimentary Geology, 225, 116-137.

Miccadei, E., D’Alessandro, L., Parotto, M., Piacentini, T., Praturlon, A., 2014. Note Illustrative della Carta Geologica d'Italia alla scala 1:50.000, Foglio 378 "Scanno". Roma, Istituto Superiore per la Protezione e la Ricerca Ambientale (ISPRA) - Servizio Geologico d'Italia, 201pp.

Migliorini, C.I., 1950. Suddivisione geografica dell'Appennino per uso geologico. Una proposta. Bollettino della Società Geologica Italiana, 68, 191-253.

Morettini, E., Santantonio, M., Baumgartner, P.O., Hunziker, J.C., 2002. Carbon isotope stratigraphy and carbonate production during the Early-Middle Jurassic: examples from the UmbriaMarche-Sabina Apennines (central Italy). Palaeogeography, Palaeoclimatology, Palaeoecology, 184, 251-273.

Parotto, M., Praturlon, A., 1975. Geological summary of the Central Apennines. In: Ogniben, L., Parotto, M., Praturlon, A. (eds.). Structural Model of Italy. Quaderni de «La Ricerca Scientifica», 90, 257-311.

Patacca, E., Sartori, R., Scandone, P., 1992. Tyrrenian basin and Apenninic arcs: kinematic relations since late Tortonian times. Memorie della Società Geologica Italiana, 45, 425-451.

Patacca, E., Scandone, P., 2013. Il contributo degli studi stratigrafici di superficie e di sottosuolo alla conoscenza dell'Appennino Campano-Lucano. Atti $1^{\circ}$ Congresso dell'Ordine dei Geologi di Basilicata, "Ricerca, Sviluppo ed Utilizzo delle Fonti Fossili: Il Ruolo del Geologo”. Potenza, 30 Novembre - 2 Dicembre 2012, 97-153.

Pierantoni, P.P., Deiana, G., Galdenzi, S., 2013. Stratigraphic and structural features of the Sibillini Mountains (Umbria-Marche Apennines, Italy). Italian Journal of Geosciences, 132, 497520. DOI: 10.3301/IJG.2013.08

Royden, L., Patacca, E., Scandone, P., 1987. Segmentation and configuration of subducted lithosphere in Italy: An important control on thrust-belt and foredeep-basin evolution. Geology, 15, 714-717.

Rusciadelli, G., Ricci C., 2013. Carbonate production of ancient debris-dominated reefs: An outcrop-based example from the Upper Jurassic reef complex of the central Apennines (Italy). Geological Society of America Bulletin, 125, 1520-1538. DOI: $10.1130 / \mathrm{B} 30850.1$

Salvini, F, Vittori, E., 1982. Analisi strutturale della linea OlevanoAntrodoco-Posta (Ancona-Anzio Auct.): metodologie di studio delle deformazioni fragili e presentazione del tratto meridionale. Memorie della Società Geologica Italiana, 24, 337-355.

Salvucci, R., 1995. Caratterizzazione geologico-strutturale della "zona d'incontro" tra il dominio sabino e quello abruzzese a nord di Antrodoco. Studi Geologici Camerti, Volume Speciale 1995/2, 397-406.

Santantonio, M., 1993. Facies associations and evolution of pelagic carbonate platform/systems: examples from the Italian Jurassic. Sedimentology, 40, 1039-1067.

Santantonio, M., 1994. Pelagic Carbonate Platforms in the Geologic Record: Their Classification, and Sedimentary and Paleotectonic Evolution. American Association of Petroleum Geologists Bulletin, 78, 122-141.

Santantonio, M., Galluzzo, F., Gill, G., 1996. Anatomy and palaeobathymetry of a Jurassic pelagic carbonate platform/ basin system: Rossa Mts, Central Apennines (Italy). Geological implications. Palaeopelagos, 6, 123-169.

Santantonio, M., Carminati, E., 2011. Jurassic rifting evolution of the Apennines and Southern Alps (Italy): parallels and differences. Geological Society of America (GSA) Bulletin, 123, 468-484.

Santantonio, M., Scrocca, D., Lipparini, L., 2013. The OmbrinaRospo Plateau (Apulian Platform): Evolution of a carbonate platform and its margins during the Jurassic and Cretaceous. Marine and Petroleum Geology, 42, 4-29.

Santantonio, M., Fabbi, S., Bigi, S., 2017. Discussion on «Geological map of the partially dolomitized Jurassic succession exposed in the central sector of the Montagna dei Fiori Anticline, Central Apennines, Italy» by G. Storti, F. Balsamo and A. Koopman (2017). Italian Journal of Geosciences, 136, 312-316.

Scarsella, F, 1951. Sulla zona d'incontro dell'Umbria e dell'Abruzzo. Bollettino del Servizio Geologico d'Italia, 71, 155-165.

Schlager, W., 1989. Drowning unconformities on carbonate platforms. Society of Economic Paleontologists and Mineralogists, 44 (Special Publication), 15-25.

Scott, R.W., 1988. Evolution of Late Jurassic and Early Cretaceous Reef Biotas. Palaios, 3, 184-193.

Servizio Geologico d'Italia, 2011. Carta Geologica d'Italia alla scala 1:1,000,000. Roma. Istituto Superiore per la Protezione e la Ricerca Ambientale (ISPRA), Last accessed: October 2021. Website: http://sgi.isprambiente.it/milione/milione5ed.html

Tavarnelli, E., Decandia, FA., Alberti, M., 1999. Evidenze di tettonica distensiva sinsedimentaria nel bacino messiniano della Laga: implicazioni per l'evoluzione dell'Appennino settentrionale. Bollettino della Società Geologica Italiana, 118, 217-227.

Vezzani, L., Casnedi, R., Ghisetti, F, 1994. Carta geologica dell'Abruzzo Nord-orientale. Scala 1: 100.000. Atti ticinensi di scienze della terra, 2 (Serie Speciale).

\footnotetext{
Manuscript received February 2021;

revision accepted July 2021;

published Online October 2021.
} 